\title{
A survey of European primitive breeds of sheep
}

\author{
M.L. RYDER \\ A.R.C. Animal Brceding Research Organisation, West Mains Road \\ Edinburgh EH9 $3 J Q$, Scotland
}

\begin{abstract}
Summary
This paper surveys the primitive (i.e. unimproved) sheep of Europe using data (notably the fleece type) from surviving breeds in place of the more commonly-used skeletal and textile remains.

Only bone evidence exists for the Neolithic sheep, and its coat is assumed to have been little different from that of the undomesticated wild ancestor. Textile remains show that Bronze Age sheep had less hairy, but still brown, fleeces like those of the Soay sheep that survives feral in the Saint Kilda islands off north west Scotland. Within this less hairy fleece type both textile remains and surviving sheep show a range of variation from relatively hairy to woolly animals.

Textile remains show that white sheep appear in the Iron Age. Much wool was, however, still coloured, having either 100 p. 100 pigmented fibres (black or brown) or some pigmented fibres and others not (grey or roan). Surviving breeds of this type (often with a primitive short tail) have a similar fleece structure to the Soay but with a range of colours, white, black and grey, in addition to the brown of the Bronze Age Soay. The present paper concentrates on this type which was probably the predominant sheep in Europe until after the Middle Ages when modern, improved breeds began to emerge.

The breeds considered to be of Iron Age type described are divided into groups as follows. The Northern Short-tail which comprises the Romanov of Rüssia, the Fivnish Landrace, the Swedish Goth, the Norwegian Spaelsau, Faroe, Iceland, Orkney-Shetland, British Four-horned and Irish Cladagh. The Corsican and Ushant breeds of France are placed with the Guirra of Spain in a South Western group, and three Heath breeds are described from the north European plain, the Drenthe of the Netherlands, the Heidsnucke of Germany and the Wrzosowka of Poland.

On Alpine group comprises the Bundner of Switzerland, the Steinschaf of Austria, and the Della Roccia of Italy, and two other Italian breeds and the Massa and Carapelle. The Balkan group includes the Racka of Hungary, the Dubrovnik of Yugoslavia with the Karakachan and Karnobat of Bulgaria, and the Drama and Chalkidiki of Greece. It was possible to include only two breeds of the Soviet Union, the Karachaev of the Caucasus, and the Kulunda of Siberia, which is included for completeness although it is not a European breed.
\end{abstract}

(1) Revised version of a paper read at the 3rd International Archaeozoological Conference, Poland, 1978. 


\section{Introduction}

Skeletal remains provide the most common source of evidence in archaeozoology, supplemented by remains derived from skin, e.g. RYDER (1962, 1973). The present paper utilises descriptions incorporating tail length, horn, colour and fleece type data of surviving unimproved breeds, and incidentally provides a compelling argument for the preservation of such breeds (RYDER, 1976).

A synthesis of biological and historical evidence on the origin of British breeds made it relatively easy to group modern breeds into broad types, and to postulate waves of introduction (RYDER, $1964 \mathrm{a}, 1968 \mathrm{a}$ ). It is less easy to discern the same patterns on the continent of Europe because the affinities are less obvious, and the greater number, and wider distribution, of breeds makes it difficult for one person to see them all (RYDER, $1968 \mathrm{~b}$; BROOKE \& RYDER, 1977, 1979).

There is no conclusive evidence for wool textile manufacture in Neolithic Europe, and it is probable that the coat of domestic sheep then had outer kemps and fine underwool, showing only a gradual change from that of the wild ancestor. Textile remains from the Bronze Age, however, coupled with skeletal remains, indicate that the sheep of this period was comparable with the Soay which now remains feral only in the Saint Kilda islands, which are outliers of the Hebrides on the very edge of the continent (fig. 1). The Soay shares with the wild ancestor: large horns in the ram, a short tail, and a moulting fleece. It also has a coloured fleece with white belly, which sets it apart from other primitive breeds. The fleece of the Soay is, however, much less hairy than the coat of the wild ancestor (see below).

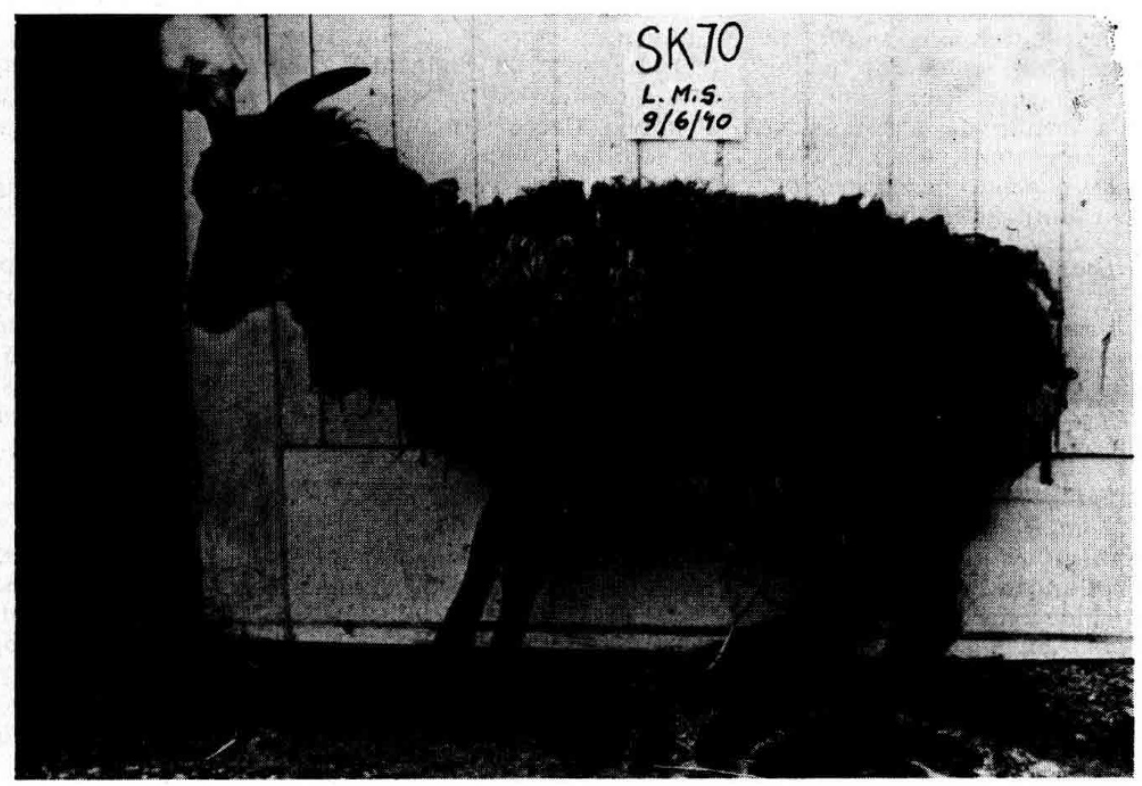

FIG. 1

The Soay breed of Saint Kilda, a survivor of the Bronze Age type Le mouton Soay de Saint Kilda, un survivant de l'Age du Bronze 


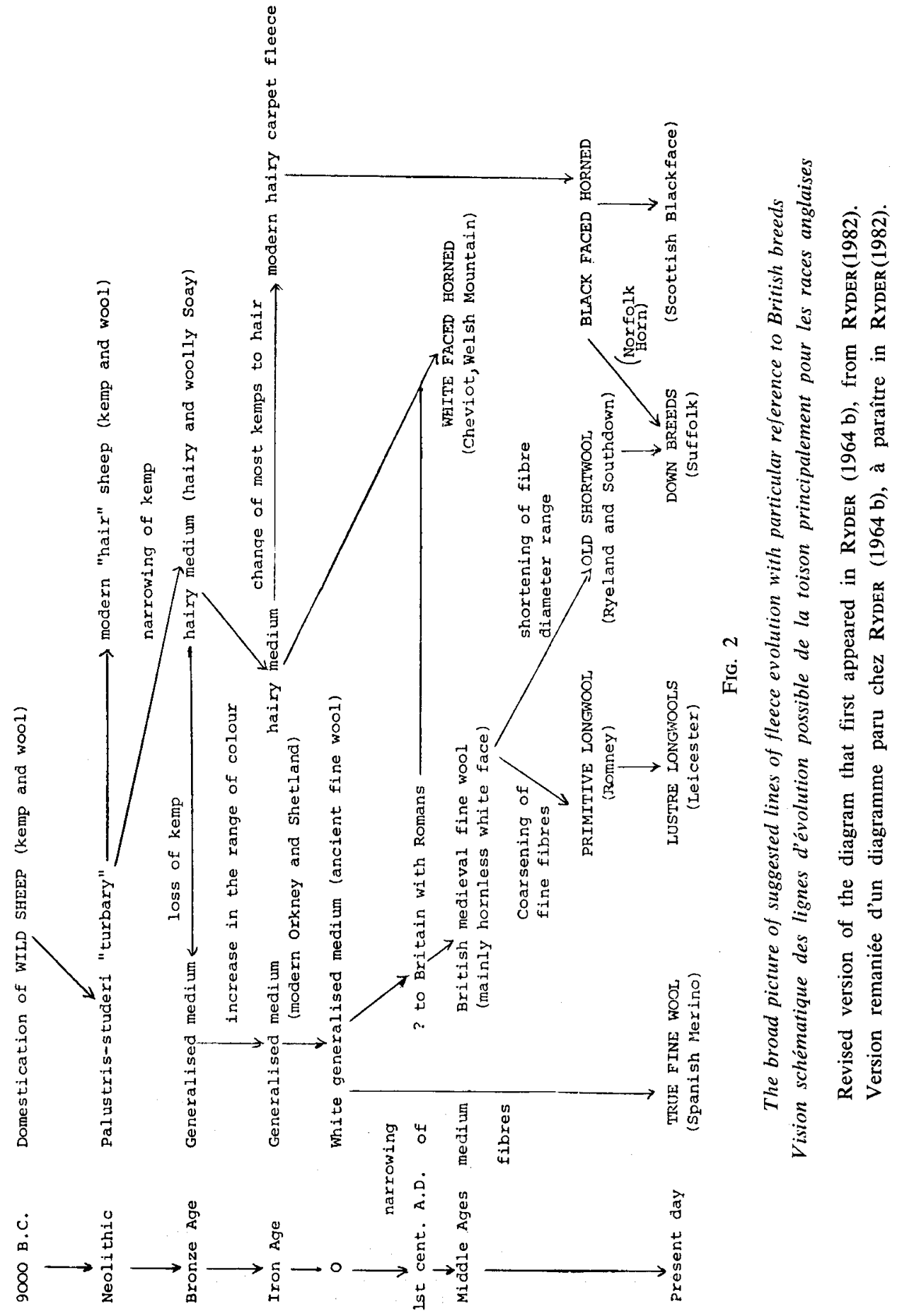


It was originally suggested (RYDER, $1964 \mathrm{a}$ and $\mathrm{b}$ ) that there was little change in British sheep until a new type was introduced about Roman times (fig. 2). Apparently, however, the European type which forms the theme of the present paper dates back to Iron Age. Textile remains indicate either all the wool fibres naturally pigmented (black or brown), some fibres pigmented and some white (grey or roan) or all non-pigmented (white). The fleece is otherwise the same as the Soay having woolly as well as hairy types in which the hairy fibres are in fact fine kemps (RYDER, $1969 \mathrm{a}$ ).

Surviving breeds of this type have a range of colours, black, white and grey, in addition to the brown of the Soay, but coloured sheep with a white belly are rare. They usually retain a primitive short tail, and the skeletal dimensions are similar to those of the Soay (fig. 5), and since they also have the same fleece structure, the main distinction from the Soay is the greater range of colour, so the type was named the (European) Short-tailed, vari-coloured by RYDER (1968 b). They seem to have been the predominant type in Europe until after the Middle Ages.

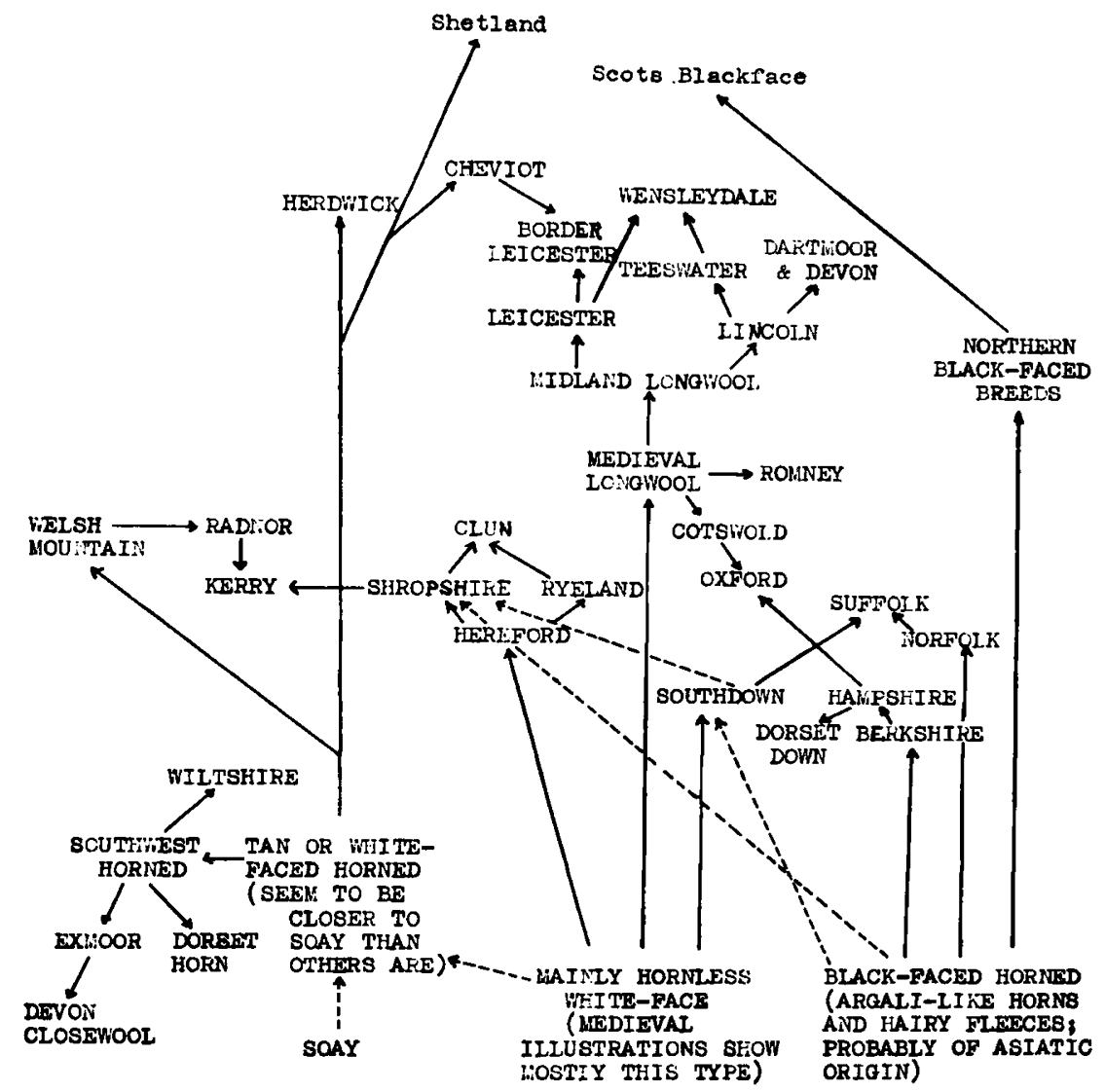

FIG. 3

The probable derivations and relationships of British sheep

(from RYDER, 1964 a)

L'arbre généalogique des races ovines britanniques

(proposé par RYDER, 1964 a) 
Textile remains indicate that most Roman sheep were white, and illustrations suggest that only the rams were horned. The suggestions of RYDER (1964 a) summarised in fig. 2, were that crosses between white, Roman sheep, and the brown, native Soay could have produced types that later emerged as breeds such as the Cheviot and Welsh Mountain to the north and west. These are horned in the rams only, and any pigment is brown rather than black. Such a derivation is no doubt too simplified if only because by the time the Romans arrived the Soay was no longer the dominant type. On its own in Britain, however, the Roman sheep could have given rise on the one hand to the primitive longwool and on the other to the shortwool. These types were found amoung Roman textiles (see below) but they did not become common until after the Middle Ages. On the continent the true fine wool was the more important type, emerging later in Spain as the Merino breed.

The third main type in Britain is the horned and hairy black-faced type. There are suggestions linking this with the Heath sheep of the North European Plain via a Danish introduction, but one need not postulate an exotic origin for every British type, although it is not yet clear how much evolution took place within Britain. The British representatives of the European vari-coloured type - the Orkney and Shetland breeds - have been associated with Norse settlers, but if this type goes back to the Iron Age they may have introduced a similar breed and not a distinct type. Fig. 3 summarises the probable origins and relationships of modern British breeds from historical records over the last 200 years.

Changes in the fleece following domestication are shown in fig. 4. The big difference in diameter between the coarse kemps of the outer coat, and the fine, woolly under coat in the wild Mouflon (top) is very striking. Fleeces of existing sheep have been used in fig. 4, but all diameter distributions (fleece types) except that of the wild animal at the top have been found in ancient textiles. The evolutionary changes that appear to have taken place are, first, a narrowing of the coarse, bristly kemp fibres forming the outer coat of the wild sheep to produce much the less-coarse, hairy fibres (fine kemps) of the hairy Soay. The underwool became a little coarser, few, if any, domestic sheep having wool as fine as that of the wild sheep. Further narrowing of the hairy fibres, presumably as a result of selective breeding by man, changed them into wool fibres of medium diameter to give the fleece of the woolly Soay. These two fleece types occur as hairy medium and generalised medium fleeces, with the same natural pigmentation as the Soay, in Bronze Age wools.

The evolutionary term generalised is used for the latter fleece type because it formed an important link. Not only was it apparently derived from a more primitive nairy type, but it was able to give rise to several more-highly evolved fleece types as follows. A continued narrowing of the medium fibres by breeding could have resulted in a fine fleece with a symmetrical diameter distribution like that of the modern Merino (fig. 4 bottom, right). If, one the other hand, the finer fibres had become coarser, then the medium wool diameter distribution of the modern longwool would have been obtained (top right). Thirdly, if both changes had taken place together, and the range of fibre diameter had become shortened, the distribution would have been comparable with that of the modern shortwool (right, middle). In this the mean fibre diameter has a value between that of the fine and medium values.

The true hairy (carpet wool) type of fleece seems to have arisen from the hairy medium wool by a change of most of the kemps into hairs (fig. 4, bottom, left). The 
origin of hairs, which are coarse and kemp-like in summer, but lack a medulla and appear like wool fibres in winter, appears to have been associated with the change from a moulting fleece to one of continuous growth (see below). The hairy, carpet fleece first appeared in the Iron Age, but was uncommon until after the Middle Ages. Most Roman wools, although white, were of either hairy medium, or generalised medium type (RYDER, 1974 a, 1981) but longwools, shortwools, and fine wools were developing at that time. A range of fleece types from hairy medium through generalised medium to true fine (rarely) has been found in the modern Orkney breed, and some Northern Short-tails have a true hairy fleece (RYDER, 1968 a).

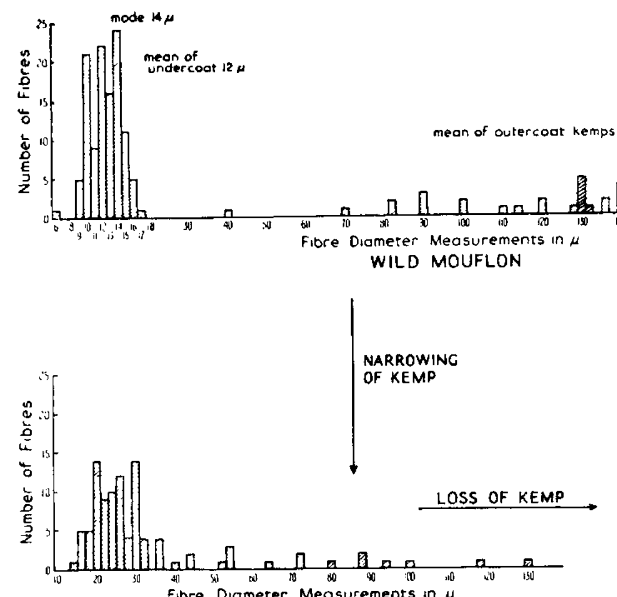

HAIRY MEDIUM WOOL (HAIRY SOAY mean $36.9 \mu$ )

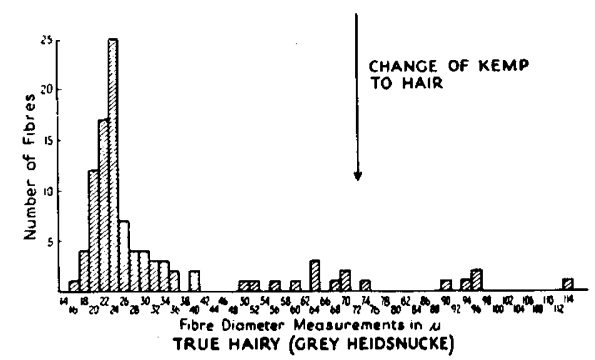

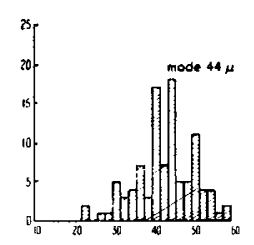

LONCWOOL (COTSWOLD mean $42.3 \mu$ ) TRUE MEDIUM DISTRIBUTION

FIG. 4

Changes in fibre diameter distribution during the domestic evolution of the fleece

Changements dans la distribution du diamètre des fibres au cours de l'évolution de la toison après domestication

In these histograms the fibre diameter is shown on the horizontal axis, and the number of fibres on the vertical axis. Revised version of the illustration in RYDER (1969 a and 1973), from RYDER (1982).

Dans ces histogrammes le diamètre de la fibre est en abscisses, le nombre de fibres en ordonnées. C'est une version remaniée de l'illustration de RYDER (1969 a et 1973), à paraître in RYDER (1982). 
In addition to allowing studies of the evolution of fleece structure, the survival of primitive breeds with a high proportion of coloured animals has allowed investigations of colour inheritance. An interpretation worked out by Adalsteinsson (1970) with Icelandic sheep, apparently also applies to Soay, Orkney and Shetland sheep (RYDER and al., 1974) and may even be universal (RYDER, 1980).



FIG. 5

The length plotted against minimum width at the mid-point of metacarpal bones from Scottish sites, and including primitive and modern breeds for comparison (from RYDER, 1968 a)

La longueur fonction de la largeur minimum au milieu du métacarpe. Observations dans des sites écossais avec mesures sur races primitives et races modernes, à titre de comparaison (RYDER, $1968 \mathrm{a})$

The Soay has light and dark brown individuals, dark animals being genetically black, and most Soays have a white belly (fig. 1). There are, however, self-colour Soays in which the belly is coloured, and dark self-coloured animals appear all black. The colour genotypes found in the Soay, Orkney and Shetland are shown in table 1. The colour pattern genes of the $A$ series are on a different chromosome from the colour genes of the $B$ series, and those higher in the series are dominant over those lower down, thus black $(B)$ is dominant over brown $(b)$ and the black phenotype can therefore be either homozygous $(B B)$ or heterozygous $(B b)$.

Brown $(a a b b)$ is the simplest (homozygous recessive) genotype; $a$ is the gene for self-colour and this is recessive to $A^{w}$ the gene for mouflon-pattern a term that Adalsteinsson use for black with white belly. In the Soay there are two genotypes for light mouflon-pattern, and four for dark mouflon-pattern. The all-black and 
all-brown genotypes of the Orkney and Shetland (and probably also of other Northern Short-tails) are the same as those in the Soay, and provide a link between these Bronze Age and Iron Age types : a polled, self-colour, light Soay with a woolly fleece is almost indistinguishable from a brown Shetland.

\section{TABLE 1}

Genetic formula for coat colour in the Soay, Orkney and Shetland

Formule génétique pour la couleur du Soay, de l'Orkney et du Shetland

\begin{tabular}{|c|c|c|c|}
\hline Phénotype & \multicolumn{3}{|c|}{ Génotype } \\
\hline Brown .. & $a \mathbf{a} b \mathbf{b}$ & & \\
\hline Black ... & a a B B & $\mathrm{a} a \mathrm{~B} \mathrm{~b}$ & \\
\hline $\begin{array}{c}\text { Dark Mouflon (black with white } \\
\text { belly) } \ldots \ldots \ldots \ldots \ldots \ldots \ldots\end{array}$ & $\begin{array}{l}\text { A }^{w} A^{w} \text { B B } \\
\text { A }^{w} \text { a B B B }\end{array}$ & $\begin{array}{c}A w A w B b \\
A w a B b\end{array}$ & \\
\hline $\begin{array}{c}\text { Light Mouflon (brown with } \\
\text { white belly) } \ldots \ldots \ldots \ldots \ldots\end{array}$ & $A^{w} A^{w} b$ b & $A w a b b$ & \\
\hline Grey .. & $\begin{array}{l}\mathrm{A}^{g} \mathrm{~A}^{g} \mathrm{~B} B \\
\mathrm{~A}^{g} \text { a B B }\end{array}$ & $\begin{array}{l}A^{g} A^{g} B b \\
A^{g} a B b\end{array}$ & \\
\hline Grey-brown & $A^{g} A^{g} b_{b}$ & $A^{x} a b b$ & \\
\hline White .... & 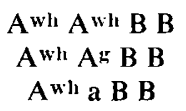 & $\begin{array}{c}A^{\text {wh }} A^{\text {wh }} \text { B b } \\
A^{\text {wh }} A^{g} \text { B b } \\
A^{\text {whl }} \text { a B b b }\end{array}$ &  \\
\hline
\end{tabular}

White $\left(A^{w h}\right)$ is dominant to grey $\left(A^{y}\right)$ and both are dominant to mouflonpattern $\left(\boldsymbol{A}^{w}\right)$ and self-colour $a$. There are at least nine white genotypes in the Orkney and Shetland breeds. The grey gene $\left(A^{g}\right)$ causes a mixture of coloured and white fibres; when the black gene $(B)$ is present the mixture is grey, for which there are four genotypes. When there is only the brown gene $(b)$ the mixture of brown and white fibres is named grey-brown, which the Norwegians name "brown skimlet », grey being termed «black skimlet». It is usually the coarsest fibres that are pigmented.

The changes in fleece and other characteristics during successive periods of antiquity are summarised in table 2 . 







\section{Material and methods}

Most breeds described in this paper have been seen by the author and the fleece measurements given were made on wool and skin samples taken at the mid-side position (immediately behind the last rib, and half way down the body). Staple length was measured against a ruler, and fibre diameter was measured at the base of the staple on 100 fibres using a projection microscope at a magnification of $500 \times$. The skin was processed histologically and follicle counts were made on horizontal sections by the method in Appendix I of RYDER \& STEPHENSON (1968).

\section{Fibre types}

Although all fibres in the fleeces of sheep are collectively named wool, there are three main types : kemps which form the outer coat of wild sheep, wool, which forms the underwool, and intermediate (heterotype) hairs. Kemps are very coarse fibres with a wide internal (hollow) medulla. Kemp is usually short since the fibres do not grow long before shedding. Wool fibres are usually fine, and any medulla is relatively narrow. Hair (in sheep) is usually long and it varies over the length (hence the name heterotype). It is relatively highly evolved (see above), and so hair is uncommon in the primitive breeds of the present paper.

\section{Criteria on which fleece type is decided}

Although the mean diameter, and the diameter distribution are taken into account, the upper limit of the diameter range is the deciding factor (see fig. 4). Thus a fleece with a symmetrical (statistically normal) distribution, and a maximum fibre diameter between 30 and $40 \mu \mathrm{m}$ [one $\mu \mathrm{m}$ (micron) $=0.001 \mathrm{~mm}$ ] would be regarded as a true fine type. The shortwool, too, has a symmetrical diameter distribution, but has a mean diameter of about $25 \mu \mathrm{m}$ compared with a mean of about $20 \mu \mathrm{m}$ in the fine wool. A skewed-to-fine diameter distribution (in which most of the fibres are fine) appears to be a primitive feature and if this occurred in a fleece with an upper limit above $35 \mu \mathrm{m}$, it would be regarded as a fine variety of the generalised medium wool (i.e. fine, generalised medium wool).

The generalised medium wool is characterised by a skewed-to-fine distribution, and a maximum diameter about $55 \mathrm{\mu m}$. The true medium wool has a symmetrical diameter distribution with an upper limit of about $60 \mu \mathrm{m}$, whereas the hairy medium wool has a skewed-to-fine distribution with a few hairs greater than $60 \mu \mathrm{m}$ diameter. The hairy type has a continuous distribution, which is at the same time skewed-to-fine, with a relatively high proportion of hairy (i.e. medullated) fibres that are often over $100 \mu \mathrm{m}$ in diameter.

\section{Secondary/primary follicle ratio}

In wild animals outer coat hairs are grown in primary follicles, and the finer underwool in secondary follicles. Since the secondary follicles produce fine fibres, 
the more secondaries a domestic sheep has, the finer will be its fleece. The mean $S / P$ follicle ratio of a breed therefore gives a measure of the relative fineness of the fleece (RYDER, 1962 ; RYDER \& STEPHENSON, 1968).

\section{Breed survey}

The breeds surveyed have been classified into different groups for convenience, and these are lister in table 3 .

\section{TABLE 3}

The main breeds surveyed

Les principales races examinées

Northern short-tail

Romanov (Russia).

Finnish Landrace

Goth (Sweden)

Spaelsau (Norway)

Faroe

Iceland

Orkney/Shetland

Four-Horn (Britain)

Cladagh (Ireland)

South-west

Ushant (France)

Corsican (France)

Guirra (Spain)

Heath

Drenthe (Netherlands)

Heidsnucke (Germany)

Wrzosowka (Poland)

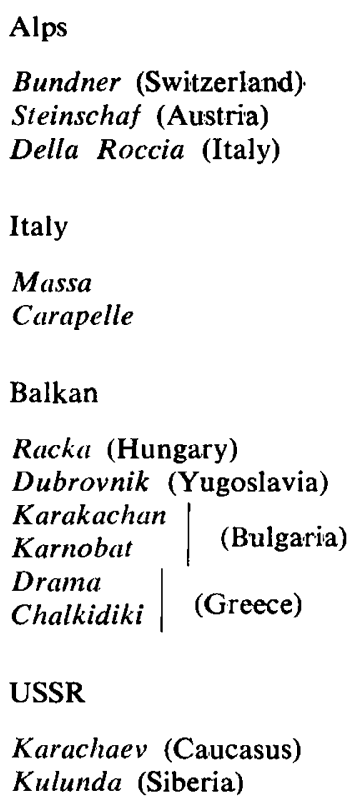

\section{Northern Short-tail}

This group of sheep has a predominantly hairy medium/generalised medium fleece type, and coloured animals are almost invariably self-coloured. 



FIG. 6

Some primitive breeds of Northwestern Europe Quelques races primitives de l'Europe du Nord-Ouest

a) Unimproved Goth Sheep, Lilla Karlsö, Gotland, 1976. Mouton Gotlandais non amélioré, Lilla Karlsö, Gotland, 1976.

b) Native Orkney breed, North Ronaldsay, Orkney, Scotland. Race Orkney indigène, North Ronaldsay, Orkney, Ecosse.

c) Schoonebeker flock of Dutch Heath Sheep, at Ruinen, the Netherlands, 1974. Troupeau de moutons des Landes de Bruyères de Hollande, type Schoonebeker, à Ruinen (Pays-Bas).

d) Heidschnucke (German Heath Sheep), 1964.

Heideschnucke (mouton des Landes de Bruyères allemand), 1964.

\section{a) Romanov and Finnish Landrace}

These hornless breeds are noted for their large litters. Most modern Romanov sheep are grey owing to a mixture of black hairy fibres and white wool, but EWART (1919) imported some all brown (presumably $b b$ ) sheep into Britain from 

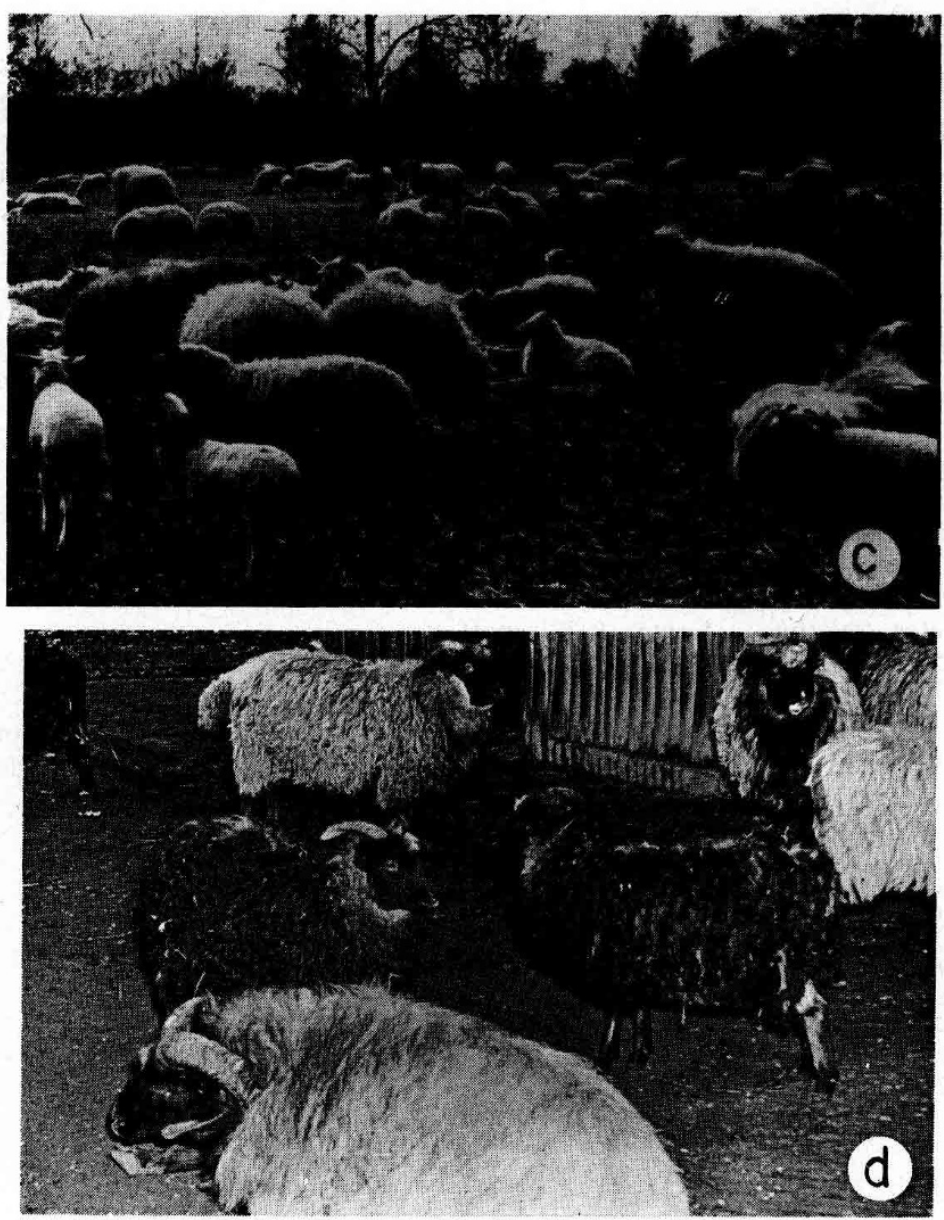

Leningrad. Most Finnish sheep are white, with 10 p. 100 black and 10 p. 100 grey. Fleece and skin measurements from RYDER $(1968 \mathrm{~b})$ are shown in tables 5 and 6 . In the Romanov the white wool was longer than the black hairy fibres which were kemps rather than heterotype hairs, so that the fleece type was hairy medium and not true hairy. The Finnish sheep mostly have relatively fine, lustrous wool with a curl. The uniformity of the group is shown by the grading of Finn wool as Shetland in Britain.

\section{b) Swedish}

Most Swedish sheep today belong to the native Landrace, a term which is now used to describe the white, fine-woolled variety that is akin to the Finnish Landrace. The majority of the Swedish Landrace sheep, however, belong to the Gotland, grey furskin variety that became localised on the Baltic island of the same name, and there is a remnant of the ancestral Goth sheep on the small island of Lilla Karslö of south-west Gotland (see fig. 6 a). The following description is based on a visit to this island by the author in june 1976 (see AdALSTEINSSON et al., 1978). 
The sheep are mainly horned (horns having been bred out of the Gotland variety) and grey, the face and legs usually being black. The fleece colour is, however, very variable ; there are light and dark grey individuals, as well as piebald animals, and many have a light-coloured belly giving them a superficial mouflonpattern. The grey colour usually derives from a mixture of black and white fibres, and some sheep have tan fibres in addition. Others had white kemp fibres that are more usual in true hairy breeds.

The rams have a height of about $72 \mathrm{~cm}$ and the ewes $68 \mathrm{~cm}$ (the sheep being characteristically long legged) and the weights are $75 \mathrm{~kg}$ and $45 \mathrm{~kg}$ respectively

TABLE 4

Fleece measurements of Northern short-tail sheep

Fibre Diameter (microns - $1 \mu \mathrm{m}=0.001 \mathrm{~mm}$ )

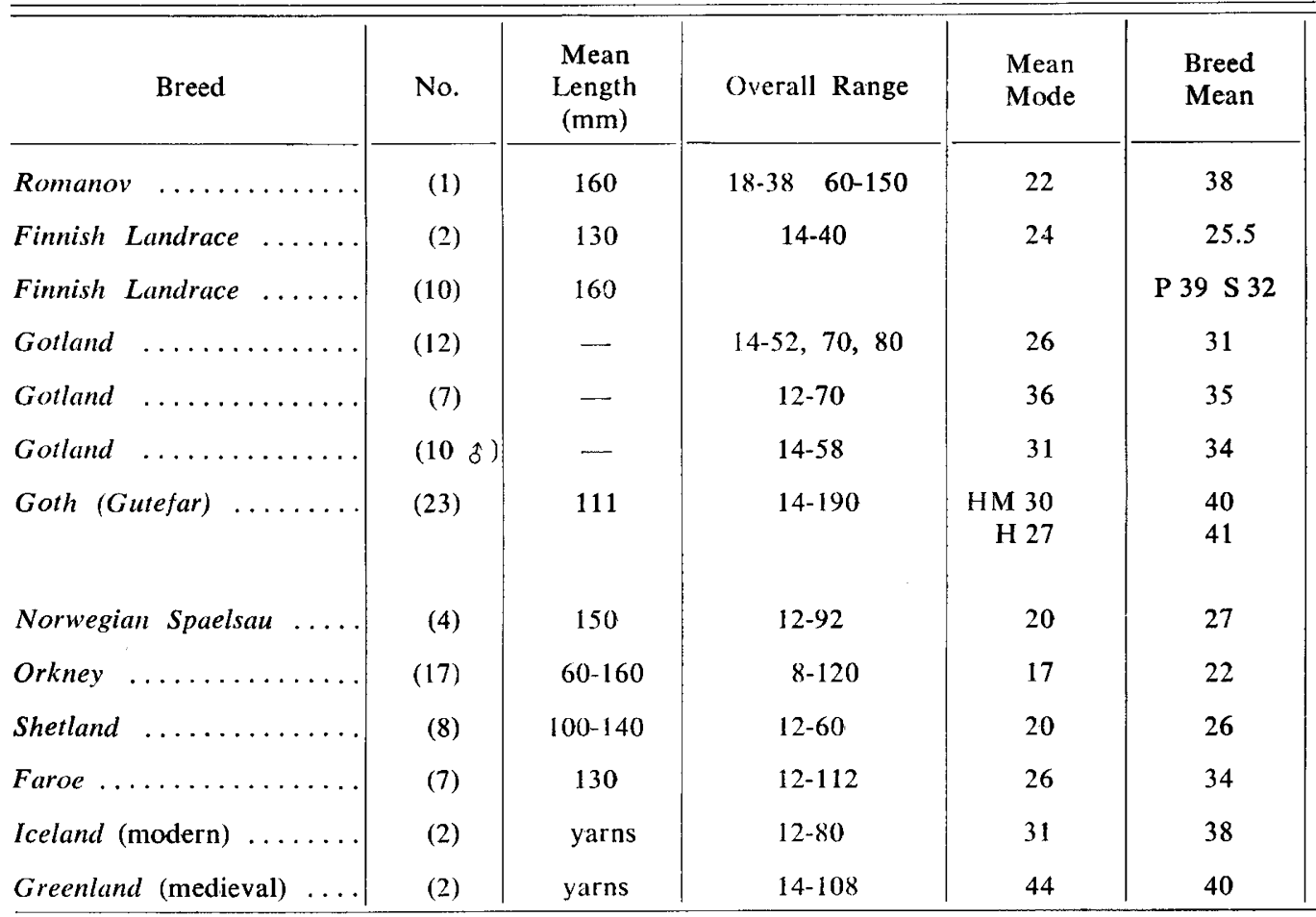

1. RYDER (1968 b).

2. RYDER (1974 b).

3. RYDER unpublished.

4. RYDER (1974 a).

5. RYDER \& WILSON (1972).

- : No measurement. 
Samples from the primitive variety on Lilla Karslö comprised nine (39 p. 100) identified as true hairy, and fourteen $(61 \mathrm{p}$. 100) as hairy medium. The overall diameter rrange was 14 to $190 \mu \mathrm{m}$, and as well as having more medullated fibres, the hairy sheep had a greater mean diameter but a smaller mode. Hairy animals also had more pigmented fibres, which is in keeping with the statement of Ekman (1964) that black hairs tended to be coarser than white ones. The skin indicated that fewer secondaries than primaries were pigmented, and that not only was the intensity of pigmentation lower, but it was concentrated on only one side of the fibre. These unimproved animals already had the unusually high $\mathrm{S} / \mathrm{P}$ ratio (table 5 ).

One hundred yarns in textiles from the seventeenth-centry Wasa warship wrecked in Stockholm harbour had on overall fibre diameter range of 10 to $140 \mu \mathrm{m}$ compared with 14-190 $\mathrm{\mu m}$ in the Lilla Karslö fleeces. There was (1 p. 100) fine wool, 5 p. 100 were shortwools, 19 p. 100 were medium wools, 13 p. 100 were generalised medium wools, 51 p. 100 were of hairy medium type and there were 11 p. 100 hairy fleeces.

The hairy wools had a mean fibre diameter (average of the individual means) of $36.7 \mu \mathrm{m}$ compared with $41.4 \mu \mathrm{m}$ in the Lilla Karslö fleeces, the values for the

TABLE 5

Percentage of different follicle types in the skin of Northern short-tail sheep

\begin{tabular}{|c|c|c|c|c|c|}
\hline \multirow[b]{2}{*}{ Breed } & \multirow[b]{2}{*}{ No. } & \multicolumn{4}{|c|}{ Primary follicles } \\
\hline & & $\begin{array}{l}\text { Latticed } \\
\text { Medulla }\end{array}$ & $\begin{array}{l}\text { Non Latticed } \\
\text { Medulla }\end{array}$ & $\begin{array}{c}\text { No } \\
\text { Medulla }\end{array}$ & $\begin{array}{l}\text { Inactive } \\
\text { Follicle }\end{array}$ \\
\hline Romanov & (1) & 78 & - & 17 & 5 \\
\hline Finnish .. & (2) & - & 一 & 94 & 6 \\
\hline Finnish & (10) & - & 0.1 & 96 & 4 \\
\hline Gotland & (7) & 12 & 22 & 66 & - \\
\hline Goth $9 \mathrm{H}$ & & 32 & 16 & 45 & 8 \\
\hline (Gutefar) $14 \mathrm{HM}$ & & 22 & 11 & 44 & 23 \\
\hline Norwegian Spaelsau & (6) & 6 & 2 & 92 & 8 \\
\hline Orkney ........... & (5) & 15 & 13 & 71 & 1 \\
\hline Shetland & (4) & - & 1 & 96,5 & 2.5 \\
\hline
\end{tabular}

The percentage of pigmented fibres varies with the colour type.

1. RYDER (1968 b).

2. RYDER (1974 b).

hairy medium wools being 31.3 and $39.7 \mu \mathrm{m}$ respectively. Therefore not only did the Wasa wools have fewer hairy fleeces, but those represented were relatively finer than those of the Lilla Karslö sheep.

The Wasa wools were comparable with a medieval group of yarns mostly from Uppsala which were supplied by $\mathrm{D}^{\mathbf{r}} \mathrm{M}$. Nockert along with some Swedish Viking wools for comparison. The medieval wools comprised ten hairy medium wools, and 
two generalised medium wools having an overall diameter range of 12 to $110 \mu \mathrm{m}$, and overall mean fibre diameter of $35.7 \mu \mathrm{m}$, and an average mode of $28.2 \mu \mathrm{m}$.

These were coarser than the Viking samples which comprised two hairy medium wools, four generalised medium wools, and two of true fine type. The overall diameter range of these was 12 to $80 \mu \mathrm{m}$ with an overall mean diameter of $29.9 \mu \mathrm{m}$, the mean mode being $25.9 \mathrm{fm}$. These findings contrast with findings from Scotland where the Viking samples were hairy, and the medieval samples relatively fine (RYDER, 1968 a). The observations of ADALSTEINSSON et al. (1978) suggested that both the Goth and improved Gotland sheep had two new grey genes $A^{g g}$ (Gotland grey) and $A^{l g}$ (light grey) at the Agouti locus.

\section{c) Norwegian}

The native short-tail of Norway is the Spael, in which the following colour types are recognised : mouflon-pattern (coloured with white belly), brown, black, some of which fade to grey, and others to brown (as in other Northern Short-tails). Then there are «skimlet» sheep with a mixture of coloured coarse fibres, and white (or paler) finer ones, so that a «black skimlet» individual appears grey, as in the Romanov or

Pourcentage des différents types de follicules dans la peau de moutons $d u$ Nord à queue courte

\begin{tabular}{|c|c|c|c|c|c|c|c|}
\hline \multirow[b]{2}{*}{$\begin{array}{l}\text { Percentage } \\
\text { Pigmented }\end{array}$} & \multicolumn{5}{|c|}{ Secondary follicles } & \multirow{2}{*}{\multicolumn{2}{|c|}{$\begin{array}{c}\text { S/P } \\
\text { Ratio }\end{array}$}} \\
\hline & $\begin{array}{l}\text { Latticed } \\
\text { Medulla }\end{array}$ & $\begin{array}{c}\text { Non Latticed } \\
\text { Medulla }\end{array}$ & $\begin{array}{c}\text { No } \\
\text { Medulla }\end{array}$ & $\begin{array}{l}\text { Inactive } \\
\text { Follicle }\end{array}$ & $\begin{array}{l}\text { Percentage } \\
\text { Pigmented }\end{array}$ & & \\
\hline 92 & 一 & - & 100 & 一 & 一 & 5.2 & [1] \\
\hline 83 & - & - & 73 & 27 & 66 & 4.5 & [1] \\
\hline- & - & - & 99 & 1 & - & 5.7 & [4] \\
\hline 58 & 0.5 & 11 & 88 & 0.5 & 22 & 6.2 & [2] \\
\hline 56 & 0.1 & 2.3 & 57 & 41 & 8 & 7.2 & [3] \\
\hline 44 & 0.2 & 1.4 & 57 & 41 & 8 & 7.1 & \\
\hline 85 & 一 & - & 86 & 24 & 64 & 4.0 & [1] \\
\hline 3 & 一 & - & 73 & 27 & 65 & 5.5 & [1] \\
\hline 15 & - & - & 90 & 10 & - & 5.5 & [1] \\
\hline
\end{tabular}

3. RYDER unpublished.

4. RYDER \& WILSON (1972).

the grey Orkney (see fig. 6 b), although the light grey shade in Norway is descrived as «blue». The «badger-face» has a white back and a coloured belly. The same range of colours is well represented in Iceland (see below).

There is also variation in coarseness (tables 5 and 6); finer fleeces tend, as in the Finn sheep, to be lustrous and to have a shallow curl, and coarse ones tend to be «tippy», i.e. to have staples with a hairy tip (RYDER, 1986 b). 
M.L. RYDER


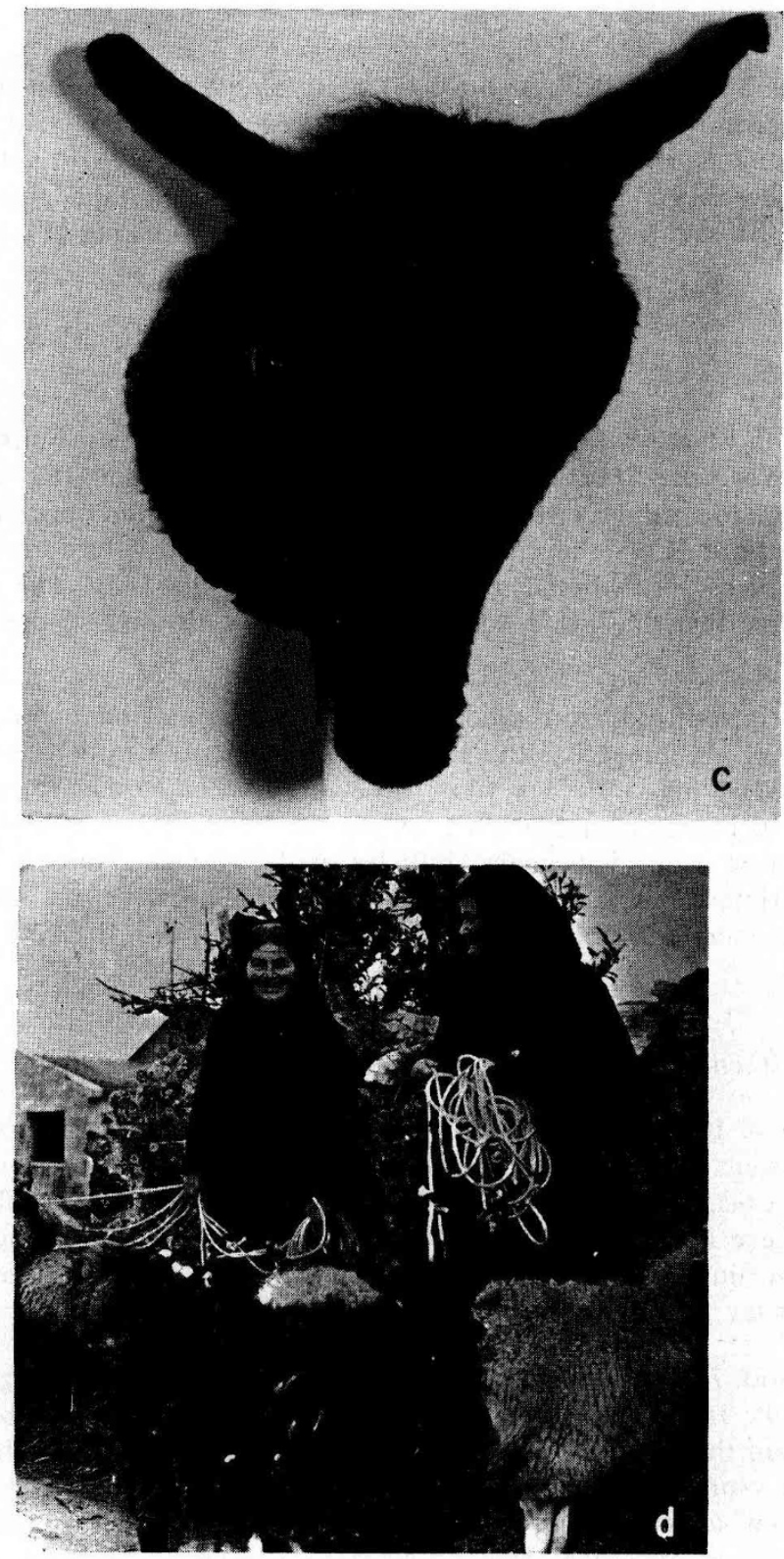

Fig. 7

$a, b, c)$ Stuffed Sheep from Lille Dimon (Faroe), now extinct : a) ram, b) and c) ewes (Photographs supplied by Tove Hatring, Zoological Museum, Copenhagen) d) The breed of the Island of Ushant (France) (c. 1960) $a, b, c)$ Têtes naturalisées de moutons de Lille Dimon (Faroe) aujourd'hui disparus : a) bélier, b) et c) brebis (Clichés fournis par Tove Hatring, Musée Zoologique, Copenhague) d) La race de lîle d'Ouessant en France vers 1960 


\section{d) Danish}

The Northern Short-tail still remained in Denmark early in the nineteenth century, but later in that century there was a Danish Heath sheep which is said to have been a cross between the Northern Short-tail and the German Heath breed. The Danish Heath has been described as white-faced, hornless and short-tailed, yet a specimen in the Zoological Museum, Copenhagen is black, horned and long-tailed (cf. German Heath below).

\section{e) Faroese}

This group of islands was settled from Norway in the early ninth century and has a breed of Northern Short-tail. A feral variety survived on the island of Lille Dimon until the middle of the last century, and there are stuffed specimens of this in the Zoological Museum, Copenhagen (fig. $7 \mathrm{a}, \mathrm{b}, \mathrm{c}$ ) because these are brown self-colour animals one cannot be sure whether or not they are like the Soay. There is, however, no reason to believe that they were not Northern Short-tails, and so the Soay remains unique.

Sheep were introduced from Shetland and Iceland in the eighteenth century, and the modern Faroese breed has the same range of colours as other Northern Shorttails, with relatively hairy fleeces like those of Icelandic sheep (ADALSTEINSSON \& WARDUM, 1978). Fleece measurements are shown in table 3. The only skin sample examined had large central primary follicles with a wide latticed medulla, and smaller lateral primaries with either a non-latticed medulla, or no meddula at all. The secondary (underwool) follicles were much smaller, and the $S / P$ follicle ratio was $4 / 1$.

\section{f) Iceland and Greenland}

Most settlers of Iceland came direct from Norway about AD 900, and present-day Icelandic sheep stem from animals introduced at that time. Most sheep today are horned in both sexes, animals sometimes having four horns, but hornless sheep are common. The fleece is hairy, the coarse outer coat having a mean length of $21 \mathrm{~cm}$, and the soft, fine underwool an average length of $6, \mathrm{tm}$. Despite the hairiness the mean fibre diameter is only $27 \mu \mathrm{m}$.

As in Shetland, Icelandic sheep were plucked in the past indicating the primitive tendency to moult. In common with the Soay, many of the hairy fibres shed at a different time from the wool, so that the wool can be obtained largely free from hair. Although in the Northern Short-tail most hairy fibres are kemps, many of those in Icelandic sheep appear to be heterotype hairs. Although heterotypes are not typical of this group of sheep, this observation supports the suggested origin of heterotype hairs from kemps (see introduction). Indeed, this occurrence may indicate a stage in the evolution towards the typical carpet type.

Present-day Icelandic sheep are mainly white, often with a tan head and feet, and varying proportions of tan fibres in the fleece, although such animals are still genetically white. From 10 p. 100 to 20 p. 100 of the sheep are coloured, black, brown, grey, brown-grey (brown skimlet) and other rare colours such as badger-face 
and reverse badger-face another name for coloured with white belly also called mouflonpattern a term which may cause some confusion. Each colour can be unbroken or broken (e.g. piebald) (AdALSTEINSSON, 1970). Norse settlers took a similar sheep to Greenland, and table 3 shows the measurement of an archaelogical specimen from that country.

\section{g) The British Isles}

A hundred years ago the sheep of the Northern Isles of Britain formed a single population. Since then the Shetland has been selected for white, fine wool, so the Orkney with hairy and woolly fleeces now represents the ancestral type. These islands were under Norse rule from the ninth to the fifteenth centuries, and the sheep show clear Scandinavian influence in their short tail, and colour range (fig. $6 \mathrm{~b}$ ). But these sheep as well as those of Scandinavia, may be relics of the Iron Age (see introduction). Fleece measurements and follicle population details are shown in tables 3 and 4. The mort primitive sheep remain now only on North Ronaldsay the most northerly island of the group (RYDER, $1986 \mathrm{a}$ and b). The other main feature of these sheep is the retention of a spring moult, so that in the past sheep were plucked instead of being shorn. The same word « roo» is used in Iceland for plucking, indicating the ancestry of the custom.

Other parts of Britain with Norse settlers include the Hebrides, the Lake District and the Isle of Man. The Hebrides formerly had a sheep similar to the Orkney and Shetland, among with four-horned and piebald animals were common. Characters from the Old Hebridean sheep probably persist in the Hebridean Blackface (RYDER, 1975). The possible relationships between the Soay, Northern Short-tail and four-horned sheep are shown in fig. 8.

Here it can be seen how selection of black, four-horned sheep could have given rise to the modern black, Saint Kilda (Hebridean) breed, and selection of brown, four-horned individuals could have led to the brown Loghtan breed of the Isle of Man. Finally, selection of piebald, four-horns could have given the Jacob breed, the origin of which has caused much speculation. Unlike the Saint Kilda and Loghtan, this does not have a short tail, and its fleece is less primitive, so other influence might be involved. But an exotic origin is unlikely when the breed could have originated in Britain.

The Herdwick of the Lake District has a hairy fleece like that of the black-faced carpet type, yet it has a white face and dark grey lambs suggesting Scandinavian influence. RYDER (1964 a) thought that the hairy fleece might have been acquired more recently, but it is now realised that such fleeces are found in Scandinavian sheep ; again this does not have a short tail.

Skeletal evidence from prehistoric sites in Ireland indicate an animal similar to the Soay, and some four-horned skulls have been found. Textile remains from the first few centuries AD yielded six hairy medium wools in which the coarser fibres were more densely pigmented than the fine ones. Seventeenth century textiles still had this difference in pigmentation between the coarse and fine fibres and comprised 14 hairy medium wools, eight generalised medium wools, four true medium wools, and one fine wool (RYDER, $1969 \mathrm{~b}$ ). 


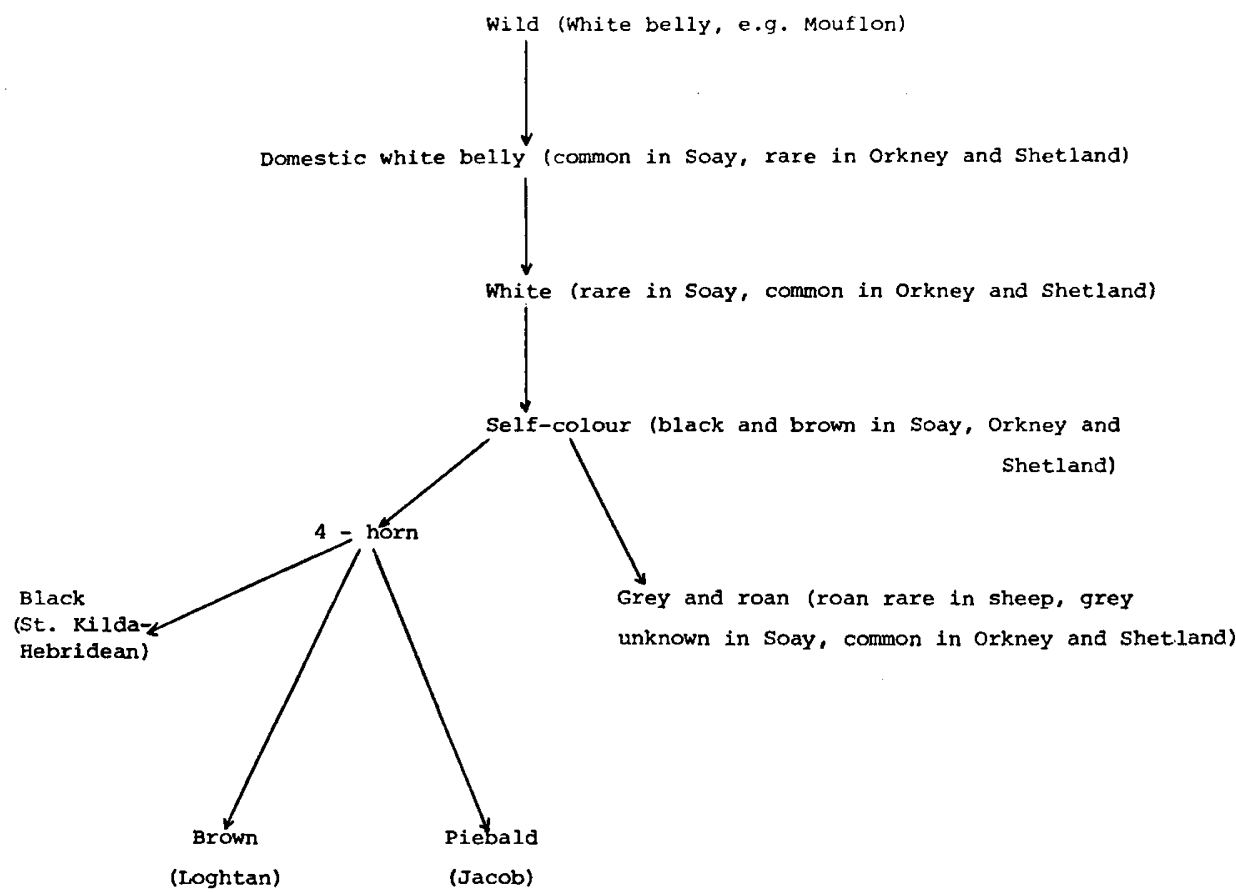

FIG. 8

Possible relationships of colour types and four-horned breeds

Rapport possible entre les types colorés et les races à 4 cornes

Descriptions and illustrations of Irish sheep do not appear until the nineteenth century, and in the west there was a horned breed known as the Kerry with a short tail and coloured as well as white sheep. Here, too, was the primitive Cladagh, and descriptions of remnants of this breed were given by NoDDLE \& RYDER (1974). One fleece samples was of hairy medium type with brown coarse fibres (as in the textile remains) being therefore brown skimlet. The overall diameter range was 12 to $70 \mu \mathrm{m}$, with a mean of $32.8 \pm 12.9 \mu \mathrm{m}$ and a mode of $20 \mu \mathrm{m}$. The secondary/primary follicle ratio in the skin was estimated to be $4 / 1$. The identification of the Cladagh with the Northern Short-tail of Britain (e.g. the Orkney and Shetland) is supported by the fact that its name means «shore sheep » because it eats seaweed like the Orkney sheep on North Ronaldsay.

Attempts have been made recently to collect together remnants of Cladagh sheep, and a flock is kept at the Belclare Research Centre, Galway. This has mostly hornless, white-faced animals, with few coloured sheep, although at least one coloured with white belly has been recorded. Results from fleece samples (RYDER unpublished) indicate that the sheep are very variable in appearance, and therefore not pure. Three samples appeared hairy and had fibre diameter measurements supporting this identification. Six had pointed staple tips but were fine and lustrous, comprising two 
generalised medium wools, two medium wools and two shortwools. Three had a broad wave, two being medium wools, and one a shortwool. Three samples appeared like British Down wool, two being shortwools, and one a generalised medium wool. Only one was coloured (grey) and this was of primitive generalised medium type. There was hardly any medullation in the skin, but the proportion of medullated fibres in the fleece samples ranged from zero to 35 p. 100 with a mean of 8 p. 100 . The S/P ratio was $3.7 / 1$, and 25 p. 100 of both the primary and secondary follicles were inactive.

\section{South West Europe}

\section{France}

The short-tailed breed of the island of Ushant (Ouessant) off north-west France was linked with the Northern Short-lail by RYDER (1968 b). The rams are horned, and the ewes polled, and there is a tendency to moult in spring. The pair with a black lamb described by RYDER (1968 b) as dark brown, are now realised to have been faded black animals. Illustrations of the island, show a predominance of white sheep, some with a $\tan$ face, but others appear to be grey, and some white sheep with a black face could be light grey animals (fig. 7 d). More recent breed descriptions list only black and «brown» animals. According to LAUVERGNe (1976) no sheep remain on the island, and in the few flocks preserved on the mainland the colour range has become reduced to all black or all white animals.

A single fleece sample measured by RYDER (1968 b) was over $100 \mathrm{~mm}$ long and had a fibre diameter range of 14 to $52 \mu \mathrm{m}$, with coarser fibres 56 and $58 \mu \mathrm{m}$ in diameter, and a mean and mode of 28 and $18 \mu \mathrm{m}$ respectively.

Illustrations of the native breed of the island of Corsica show it to have a hairy, carpet-type fleece, and the sheep appear to have the same colour range as the Northern Short-tail. LAUVERGNE \& ADALSTEINSSON (1976) found that the colour patterns were determined by a series of six alleles at the Agouti locus. Five of these : white, grey, badgerface, black with white belly and black are the same as those in Iceland. The sixth, producing a red patch around the eye has so far only been found in Corsica. In all, six out of nine colour genotypes were the same as in Iceland from which the authors concluded that the sheep of the two islands had a common ancestry. This conclusion supports the theme of the present paper, namely, that during the Iron Age and for some time later, the sheep of Europe were of vari-coloured stock. How this conclusion is affected by the fact that Corsica was never invaded by the Celts (DE BEER, 1965) is not clear.

\section{Spain}

There are references to coloured sheep in Spain going back to antiquity when Pliny mentioned black and brown sheep (Natural History VII, 191). In the nineteenth century Majorca in the Balearic Islands had a primitive breed named the Arta (Salvator, 1897). This was horned, and apparently had a short tail. The body was 
white, and the face tan, with two white stripes. One primitive sheep on Ibiza was described as black, and to have small horns and wool of medium quality. Another was said to be polled, and to have a short tail.

Apparently the only coloured breed remaining on the mainland is the Guirra kept on the coast opposite the Balearic Islands (BROOKE \& RYDER, 1977). All except 5 p. 100 of the animals which are black, are born reddish-brown and become paler with age, the final colour being cream. ADALSTEINSSON (1970) identifies this colour as «red» like that in the French Sologne breed which is also born « red» and goes paler with age.

Of the five fleece samples taken, one animal had wool of almost Merino fineness, ranging in diameter from 16 to $36 \mu \mathrm{m}$ with a mean of 24.6 and a mode of $27 \mu \mathrm{m}$, but its $\mathrm{S} / \mathrm{P}$ ratio was only 5.7, lower than expected even for a Merino cross. The remaining flour fleece samples had hairy fibres (mean percentage of medullated fibre 14.25 p. 100) in addition to the bulk of the coat which ranged up to about $50 \mu \mathrm{m}$ in diameter. The mode of each was $24 \mu \mathrm{m}$, but the means ranged from 27.3 to 34.8 , with an overall mean of $31 \mu \mathrm{m}$. The mean $\mathrm{S} / \mathrm{P}$ ratio in the skin was 5.4/1. By the classification of RYDER (1969 a) these are hairy medium wools.

\section{Heath sheep}

This group of black-faced horned sheep formerly extended from the Netherlands to Poland. Some of the breeds have a short tail, and a hairy fleece, and RYDER (1964 $\mathrm{a}$ and $1968 \mathrm{~b})$ thought from their general appearance and fleece type, that they had links with the black-faced, horned group of Britain. The grey fleece and short tail, however, probably indicate a closer association with the Northern Short-tail.

\section{Netherlands}

The three breeds of Heath sheep of Holland are the Drenthe localised in the north east, the Veluwe which occurred in belt across the middle of the country, and the Kempen breed of the south. The Drenthe is mostly horned, and has a straight nose ; the fleece is hairy and variable in colour, as is the face which can be black, tan or white. The Veluwe breed is larger and related to the German Bentheim breed. This sheep is mostly hornless, the nose is convex, and there is black around the eyes and on the legs. The fleece is less hairy. The lambs of both the Drenthe and Veluwe breeds are piebald to about the age of 6 months.

The Kempen breed is hornless and white, as are the lambs, and the hair on the face is «shiny ». Each of the three breeds has a long tail, although some descriptions referred to the Drenthe breed as having a short tail. Although the Kempen is now rare, the characters of the Drenthe and Veluwe are retained in the Schoonebeker (cf. fig. $6 \mathrm{c}$ ) hybrid of which one flock is kept at Ruinen.

This has horned and hornless animals and varying face colours (fig. $6 \mathrm{c}$ ). These are black, tan, together with patterns including speckled, black around the eyes, and 
badger-face. AdAlsteinsson (1970) points out that tan-faced sheep are genetically white, the tan fibres being restricted from the fleece since the animals are homozygous for the recessive colour-restricting gene (ss), see also the genetic analysis by LaUvergne \& BotTema (1978) (cf. the rare Portland breed in Britain). The colour of the fleece is black, brown, grey, white or piebald, and the wool is generally hairy, but is more akin to that of a hairy Shetland sheep (hairy medium type) than the true hairy fleece of the Scottish Blackface. Some animals had cast parts of their fleece.

The legs and tail are long and thin, and $D^{r}$ A.C.Y. VAN BEMMEL pointed out in 1974 that the so called Drenthe sheep I had sampled is Amsterdam Zoo in 1964, and published as such (RYDER, 1968 b) were in fact German Heath sheep (fig. $6 \mathrm{~d}$ ).

Fleece measurements of wool samples taken in 1974 are shown in table 6. These can be compared with a group of 17 yarns from Dutch Terpen sites dating from throughout the first millenium A.D. These comprised 3 hairy fleeces, 10 hairy medium wools, 2 generalised medium wools, 2 true medium wools, and one fine wool (RYDER, unpublished).

\section{Germany}

The Heidschnucke of Germany has a black face, horns, and a short tail. The colour is grey, and the lambs are born black, but the sheep frequently have a black belly like the badger-face genotype of the Northern Short-tail. There also appear to be some brown animals. The fleece is hairy (table 6) but there is a hornless white variety with a less coarse fleece. The hairy fibres include kemps as well as heterotype hairs. The $\mathbf{S} / \mathbf{P}$ follicle ratio of 4.4 indicates a greater proportion of fine fibres compared with the Scottish Blackface $(\mathrm{S} / \mathrm{P}=3.7)$.

\section{Poland}

The Wrzosowka breed appears to have affinities on the one hand with the Heidschnucke, and on the other hand with the Romanov of Russia (see table 7). The colour is predominantly grey, but NAWARA (1976) reported 10 p. 100 black animals, with about 50 p. 100 dark grey and 40 p. 100 light grey in an experimental flock at Cracow. Of 20 skin and fleece samples received from the same source 5 were dark grey, 3 medium grey, and 12 light grey. The length of three months growth of wool was about $80 \mathrm{~mm}$. The fibre diameter measurements are shown in table 5 and skin follicles details in table 6. Twelve samples were indentified as true hairy type, and eight as hairy medium wools. Another (tailed) breed of Poland is the Swiniarka, which is white faced, and horned in the rams only. It appears to have a hairy medium fleece (JANKOWSKI, personal communication).

\section{Alps}

The Bundner breed of Switzerland shares the distinction of the Soay in Britain of being a sheep whose skeleton was compared with prehistoric remains found during the nineteenth century. It has therefore appeared frequently in the literature (e.g. 
TABLE 6

Fleece measurements of Heath and Balkan sheep

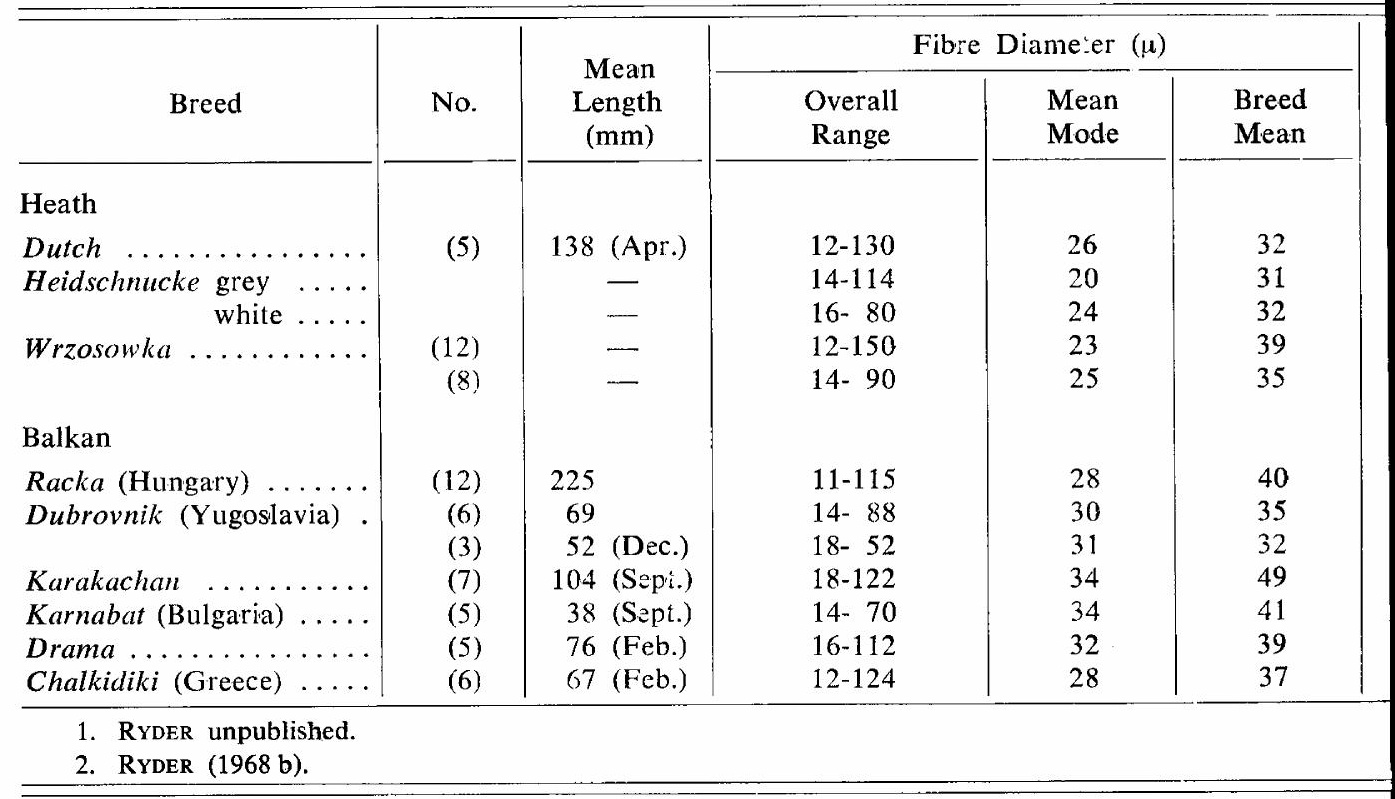

TABLE 7

Skin follicle details of Heath and Balkan sheep

\begin{tabular}{|c|c|c|c|c|c|}
\hline \multirow[b]{2}{*}{ Breed } & \multirow[b]{2}{*}{ No. } & \multicolumn{4}{|c|}{ Primary follicles } \\
\hline & & $\begin{array}{l}\text { Latticed } \\
\text { Medulla }\end{array}$ & $\begin{array}{l}\text { Non Latticed } \\
\text { Medulla }\end{array}$ & $\begin{array}{c}\text { No } \\
\text { Medulla }\end{array}$ & $\begin{array}{l}\text { Inactive } \\
\text { Follicle }\end{array}$ \\
\hline Heath & & & & & \\
\hline $\begin{array}{l}\text { Heidschnucke grey ....... } \\
\text { Wrzosowka .......... }\end{array}$ & $\begin{array}{r}(3) \\
12 \mathrm{H} \\
8 \mathrm{HM}\end{array}$ & $\begin{array}{r}75 \\
5 \\
-\end{array}$ & $\begin{array}{r}15 \\
8 \\
14\end{array}$ & $\begin{array}{l}10 \\
77 \\
77\end{array}$ & $\begin{array}{c}0.5 \\
10 \\
9\end{array}$ \\
\hline Balkan & & & & & \\
\hline 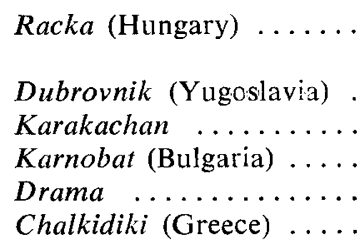 & $\begin{array}{l}(12) \\
(9) \\
(7) \\
(5) \\
(5) \\
(6)\end{array}$ & $\begin{array}{c}2 \\
\text { («medullated ») } \\
0 \\
7 \\
0 \\
0 \\
0\end{array}$ & $\begin{array}{r}1 \\
31 \\
2 \\
0 \\
5\end{array}$ & $\begin{array}{l}97 \\
62 \\
92 \\
87 \\
64\end{array}$ & $\begin{array}{r}11 \\
\\
2 \\
0 \\
6 \\
13 \\
31\end{array}$ \\
\hline
\end{tabular}

1. RYDER unpublished.

2. RYDER (1968 b). 
Mcsures sur des toisons de moutons des Bruyères et de moutons des Balkans

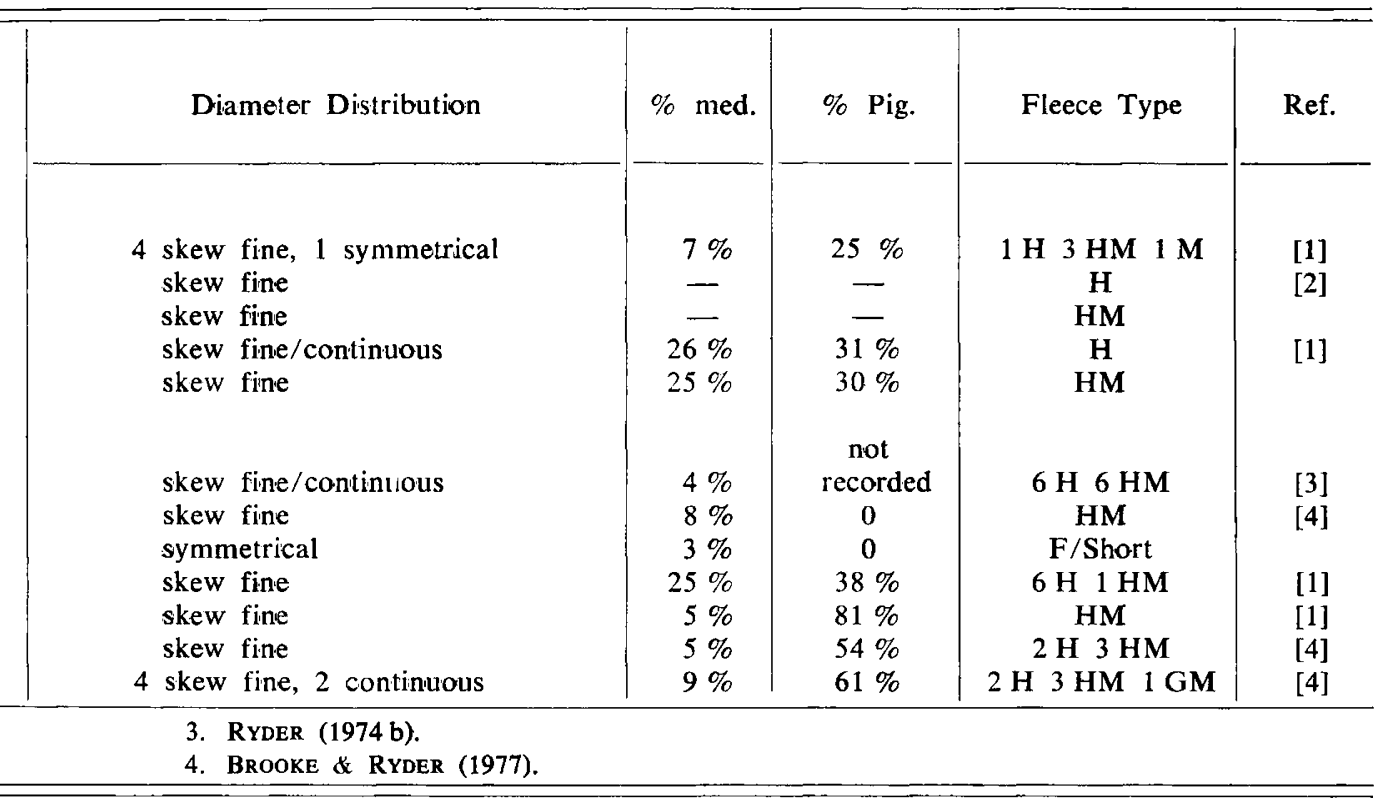

Détails sur les follicules des moutons des Bruyères et des Balkans

\begin{tabular}{|c|c|c|c|c|c|c|c|}
\hline \multirow[b]{2}{*}{$\begin{array}{l}\text { Percentage } \\
\text { Pigmented }\end{array}$} & \multicolumn{5}{|c|}{ Secondary follicles } & \multirow{2}{*}{\multicolumn{2}{|c|}{$\begin{array}{c}\text { S/P } \\
\text { Ratio }\end{array}$}} \\
\hline & $\begin{array}{l}\text { Latticed } \\
\text { Medulla }\end{array}$ & $\begin{array}{c}\text { Non Latticed } \\
\text { Medulla }\end{array}$ & $\begin{array}{c}\text { No } \\
\text { Medulla }\end{array}$ & $\begin{array}{l}\text { Inactive } \\
\text { Follicle }\end{array}$ & $\begin{array}{l}\text { Percentage } \\
\text { Pigmented }\end{array}$ & & \\
\hline 16 & 0.3 & 1 & 97.5 & 1.2 & 11 & 4.4 & {$[1]$} \\
\hline 22 & 0 & 0 & 92 & 8 & 10 & 4.8 & \\
\hline 37 & 0 & 0 & 87 & 13 & 16 & 4.3 & \\
\hline $\begin{array}{l}\text { not } \\
\text { recorded }\end{array}$ & 0 & 0 & 70 & 30 & $\begin{array}{l}\text { not } \\
\text { recorded }\end{array}$ & 2.4 & [3] \\
\hline 0 & 0 & 0 & 97 & 3 & 0 & 4.7 & [4] \\
\hline 15 & 0 & 0 & 99 & 1 & 27 & 3.9 & [1] \\
\hline 83 & 0 & 0 & 99.5 & 0.5 & 77 & 5.0 & [1] \\
\hline 15 & 0 & 0 & 96 & 4 & 16 & 3.2 & [4] \\
\hline $\begin{array}{l}\text { not } \\
\text { recorded }\end{array}$ & 0 & 0 & 88 & 11 & $\begin{array}{l}\text { not } \\
\text { recorded }\end{array}$ & 3.3 & [4] \\
\hline
\end{tabular}

3. RYDER (1974 b).

4. BROOKE \& RYDER (1977). 

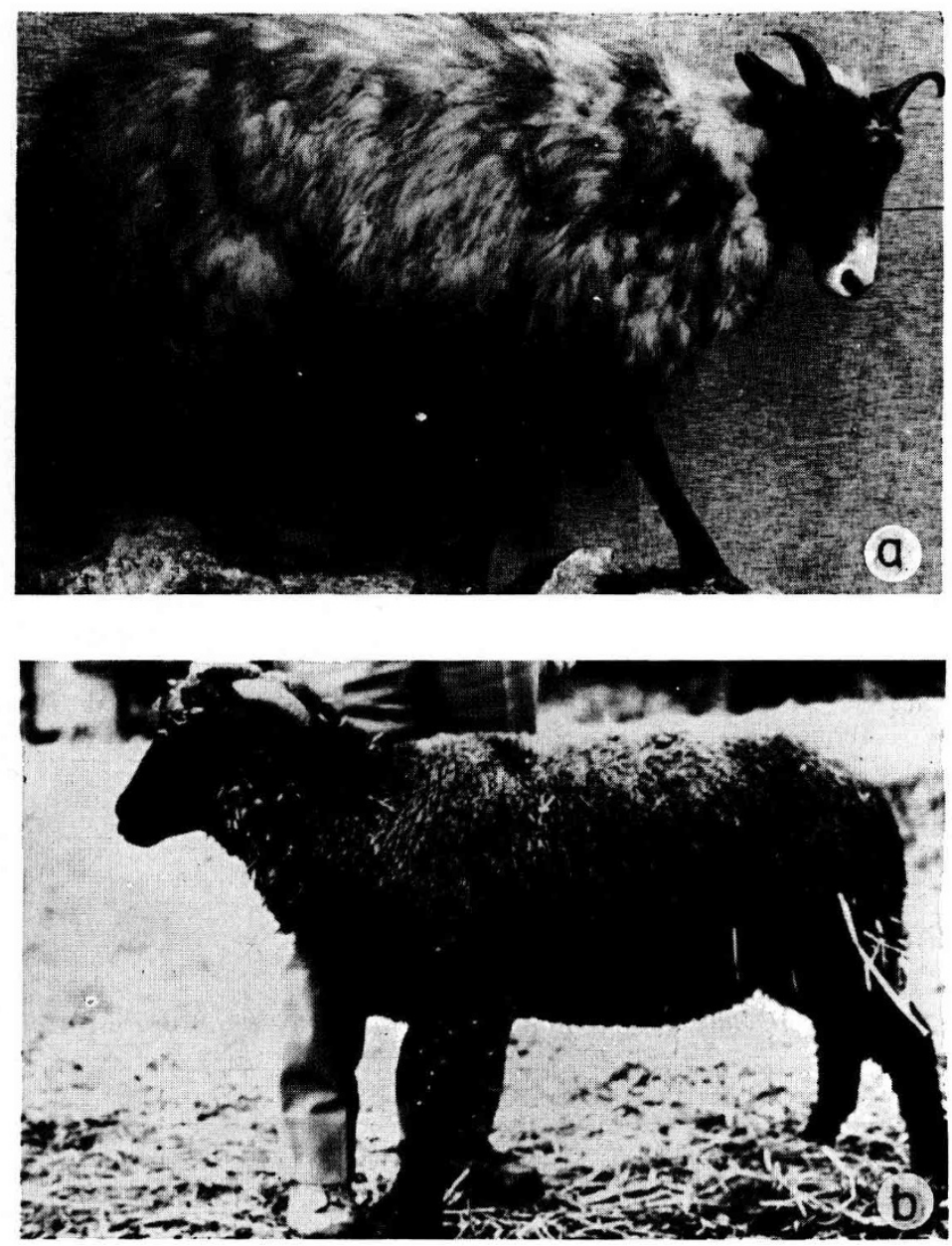

FIG. 9

Some breeds from Switzerland, Italy and the Balkans Quelques races de Suisse, Italie et des Balkans

a) A stuffed specimen of the extinct Swiss Bündner Sheep. Tête naturalisée du mouton des Grisons, aujourd'hui disparu.

b) The Carapella breed of Italy (1975) (photograph C.H. BROoKE). La race Carapella d'Italie (1975) (cliché C.H. BROOKE).

c) The Racka breed of Hungary (1971).

La race Racka de Hongrie (1971).

d) The Karakachan breed in Bulgaria (1976).

La race Karakachan de Bulgarie (1976). 

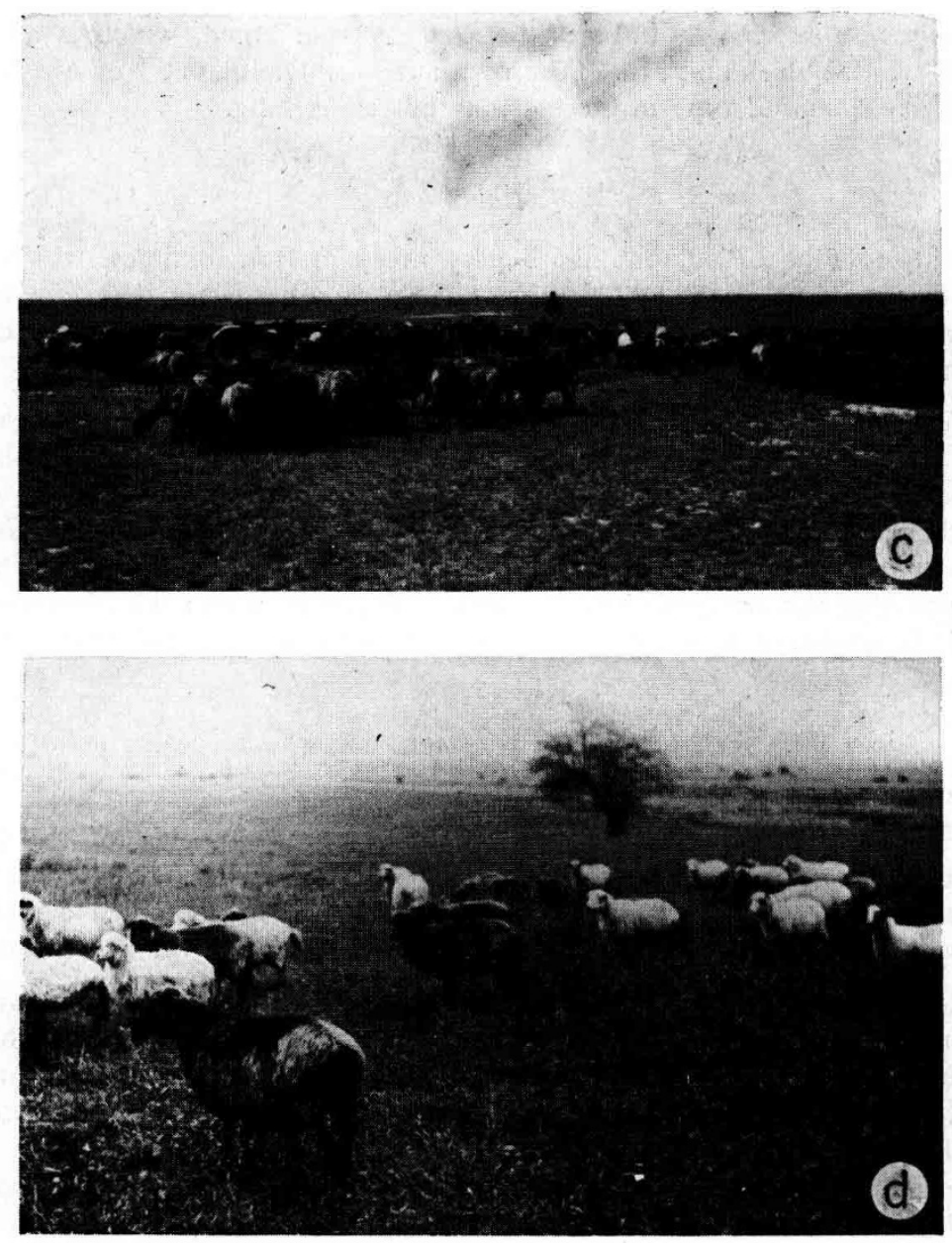

ZEUNER, 1963) but with inadequate breed description. Sadly the sheep became extinct in 1960. In the Grisons Museum, Chur, in 1976 I saw the stuffed skin of the last (brown) sheep to die. I also saw the grey animal illustrated by previous authors such as Zeuner (fig. 9 a). The tail was of medium length, but the fleece was of hairy medium/generalised medium type like the Northern short tail, and not as hairy as that of the Heath sheep. The face and legs were black. The small horns described by others as "goat-like» probably indicate the presence of the polling gene (ADALSTEINSSON, 1977).

The Steinschaf of Austria seems to be similar to the Bundner, and both appear to be representatives of a type that was formerly more widely distributed throughout the Alpine region including Bavaria and Italy (see below). The rams are usually horned and the ewes polled, and there are black, brown, and grey animals in addition white. 
The Steinschaf is seen in Italy as the Della Roccia breed, which is addition to white, has 37 p. 100 black and 3 p. 100 brown animals. The plate 51 of MASON (1967) suggests a hairy Shetland type of fleece, but the tail is long.

\section{Italy}

According to Pliny, Piedmont had a grey sheep in Roman times, which accords with the Della Roccia above. The Massa breed of Tuscany has either dark grey or brown sheep. Illustrations in breed literature indicate a primitive fleece, but the tail is of medium length.

The Carapelle of Foggia has been described as a black Merino. The survey of BROOKE \& RYDER (1977) located only one ewe remaining (fig. $9 \mathrm{~b}$ ). This was a horned sheep with faded black wool having a mean fibre diameter of $31 \mu \mathrm{m}$ and an $\mathrm{S} / \mathrm{P}$ follicle ratio of 5.3. Samples taken from the local fine-woolled Gentile di Puglia for comparison had a mean fibre diameter of $25 \mu \mathrm{m}$ and an S/P ratio of 8.9. This suggested that the carapelle has a primitive fleece type like the Northern Shorttail, since it is neither a fine wool nor a carpet type. But the tail does not appear to be short.

\section{Balkan}

Previous authors have divided Balkan sheep into the hairy Zackel type, and the finer-woolled Ruda. The survey of BROOKE \& RYDER (1977) obtained evidence that the primitive type might exist among the Zackels rather than the Ruda sheep.

The Racka of Hungary (fig. $9 \mathrm{c}$ ) has corkscrew horns in both sexes and there are black and white varieties, the face and legs of the latter being tan (cf. the Dutch Heath). The fleece is less hairy than the carpet type, half being hairy medium fleeces, more curly, and sometimes lustrous (RYDER, $1974 \mathrm{~b}$ ). Fleece measurements are shown in table 5. There was no difference in fibre diameter between black and white animals, nor between the sexes. There were apparently no kemp fibres, and the coarser fibres of the black fleeces tended to be more densely pigmented than the finer ones, which is a common feature in the Northern Short-tail. Follicle population details are given in table 6. The $\mathrm{S} / \mathrm{P}$ follicle ratio of 2.4 was low, being even less than the figure of 3.7. in the Scottish Blackfare.

The Dubrovnik breed of Yugoslavia is hornless and white-faced, and has a long tail ; 10 p. 100 of the sheep are coloured. The accepted view is that this breed originated from a fairly recent cross between the Merino, and the local hairy Zackel type, and some of the fleeces were relatively fine (table 5). But the $S / P$ ratio figure of 4.7 obtained by BROOKE \& RYDER (1977) (table 6) was lower than that expected from a Merino cross. The Merinos that are known to have been introduced are likely to have had an S/P ratio of at least as high as 10 , and so the Dubrovnik would be expected to have an $\mathrm{S} / \mathrm{P}$ intermediate (6.6.) between this and the Yugoslav Zackel value of 3.3 .

It therefore seems more likely that the Dubrovnik breed is a relic of an ancient fine wool, which accords with historical evidence of the area in classical times and during the Middle Ages. The fine fleeces, were, however, much closer to the true fine wool, than those found elsewhere in the Balkans (see below). 
TABLE 8

List of Bulgarian sheep breeds according to various authors

Liste des races ovines de Bulgarie selon divers auteurs

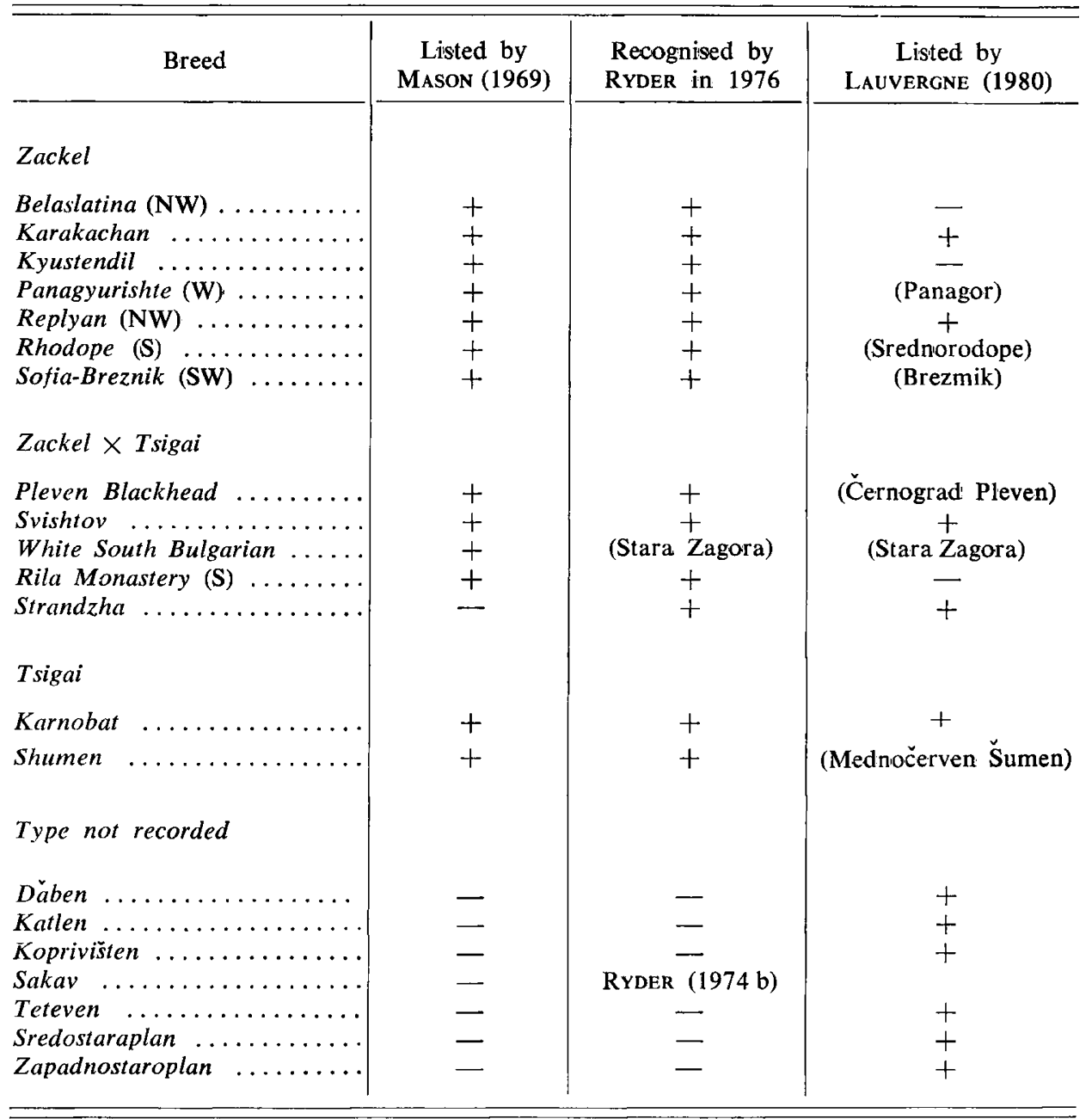

\section{Bulgaria}

MASON (1969) listed the Karnobat and Shumen as the only medium wool breeds in Bulgaria along with ten Zackel breeds (table 8). The Karakachan and Karnobat were included in the present survey as the only Bulgarian breeds discovered with a coloured fleece of primitive structure. During a visit in 1980 LAUVERGNE obtained evidence of 
more breeds (table 8) but it is not clear to what extent these are varieties of other breeds, or their names synonyms. More details of Bulgarian breeds are given by RYDER (1982). The Karakachan breed is associated with the nomadic Sarakatsan shepherd people, and so is found in other Balkan countries, notably Greece. Only two hairy fleece samples were obtained in Greece by Brooke \& RYDER (1977, 1979); another flock was seen and sampled in Bulgaria by the present author in september 1976. The samples comprised 6 hairy fleeces, and one hairy medium wool. There were black, brown, grey and white sheep, the colour being very variable, even over the body, and some of the grey animals appeared to have become so with age (fig. 9 d). The dark grey animals were typically black on the face and legs, while some light ones had a white face or black around the eyes. According to Adalsteinsson (1977) this pattern is brought about by the effect of the piebald (colour restricting) gene on recessive black, which also makes the body white. The fleece measurements and skin follicle details are given in tables 6 and 7. The hairiness of the fleece is indicated by the high mean diameter and average mode, as well as the high percentage of medullated fibres (table 6).

The Karnobat breed of Bulgaria is of less-coarse Ruda type, and has been thought to have associations with the Tsigai (Ruda) breed of Romania, which in turn is thought to be related to the Thraki breed of Greece and the Kivircik of Turkey. My observations in Bulgaria showed it to be similar to the Drama of Greece (see below) and the Panagyrurishte and Shumen (Bulgarian) breeds, and BALEvsKa \& PETRov (1972) consider from skull measurements that the last two breeds and the Karnobat are of Zackel rather than Tsigai type.



FIG. 10

Some breeds from Greece and U.S.S.R. Quelques races de Grèce et d'U.R.S.S.

a) The Drama breed of Greece (1975).

La race Drama de Grèce (1975).

b) The Karachaev breed of the Caucasus (1979).

La Karachaev du Caucase (1979).

c) The Kulunda breed of the Altai Steppe in Siberia (1979).

La race Kulunda des Steppes de l'Altai, en Sibérie (1979). 

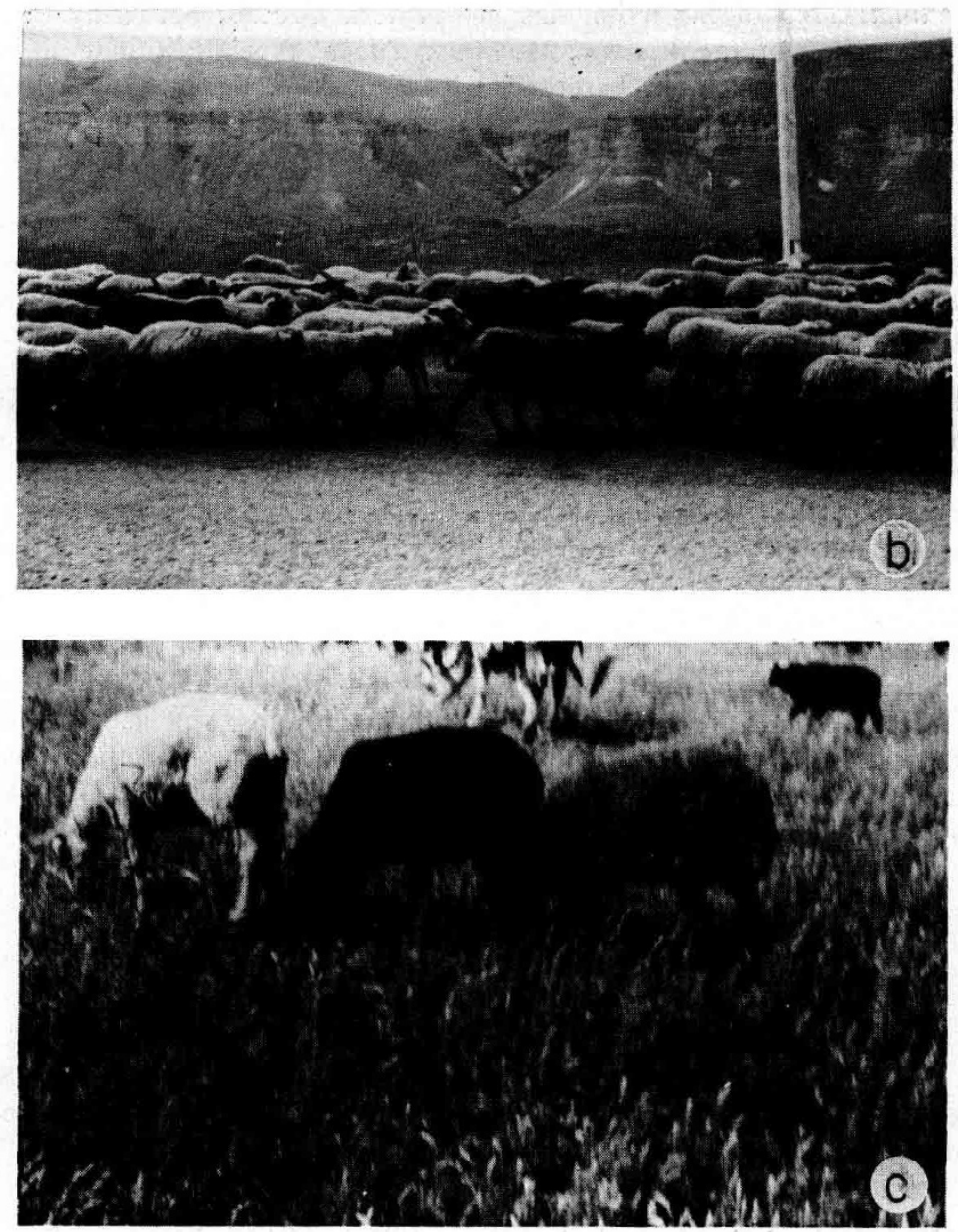

The Karnobat sheep I saw were horned in the rams only, and the tail which had been short is now long, or of medium length. The fleece appeared to be of hairy medium/generalised medium type, and not hairy. The animals were brown, but different from the usual brown in that the head and legs were black. The sheep therefore appear to be genetically black, but with a tendency to fade readily to brown (as seen in the black patchse of the Jacob breed (see also LAUVERGNE and al., 1981 for the fading process). This conclusion is supported by the observation of darker patches on the body, and of a range of shade between individuals from almost black to light brown. Some sheep appeared to have faded to grey, but no true grey animals (with black and white fibres) were observed. The same colour was observed by Adalsteinsson, Dolling, Lauvergne \& Ryder in Merinos in Australia, and may be a different genotype from black and brown (RYDER, 1980). Fleece measurements and skin follicle details are shown in tables 6 and 7. 
The Drama breed of the mountains in northern Greeces bordering on Bulgaria is probably a variety of the Vlachos Mountain Zackel type illustrated in Plate 110 of MASON (1967). The black sheep recorded by BROOKE \& RYDER (1977) had a relatively finer fleece than the remainder (fig. $10 \mathrm{a}$ ) and were also similar to the Chalkidiki breed (see below).

As with other Greek breeds the appearance was very variable, there were horned and hornless sheep, black, white and grey fleeces, speckled faces and legs, as well as black around the eyes, and a moderately long tail. Fleece measurements are shown in table 6 and skin follicle details in table 7.

I had hoped to find the remnants of an ancient fine wool in the Balkans, and was looking for a true fine wool. In the event this and the following breed provided the answer with a generalised medium fleece, which was what RYDER (1969 a) identified as the ancient fine wool. It was immediately obvious that the sheep had fleeces similar to the Shetland, and this accorded with the theme of the present paper - the primitive type surviving in southern Europe, being the same as that in the North.

The Chalkidiki breed of the peninsular of the same name in southern Macedonia has horns in the rams only, and a tail of medium length. Ten per cent of the animals were black, and there were dark and light grey, as well as white sheep. In these the face, legs, and sometimes the belly, were black, although others were white, speckled, or had black around the eyes. Somes of the animals had fine kemps as in the hairy Shetland; fleece measurements are shown in table 6 skin follicle details are given in table 7 . The similarity of the $\mathrm{S} / \mathrm{P}$ ratio with that of the Drama breed suggests a relationship between the breeds.

\section{Soviet Union}

Since it is not known how many truly native breeds remain in the U.S.S.R., and since those known in the west are not well documented, the following coloured breeds recorded during a visit in 1979 will be described.

The Karachaev (fig. $10 \mathrm{~b}$ ) is a mainly black, horned breed with a fat tail and a carpet-wool fleece, and 20000 are still kept privately in the Caucasus Mountains. Unlike more modern Russian breeds it is kept outside all the year. There is 115 p. 100 lambing, although twins have not been encouraged because of the custom of transhumance in which the sheep are taken to the high mountains during the summer. It is a triple purpose breed, the lambs being killed at one month so that the ewes can be milked. The curly, black lamb skins are used to make hats.

The ewes produce $1.5 \mathrm{~kg}$ of wool in two shearings, and weigh $35 \mathrm{~kg}$, while the rams reach $55 \mathrm{~kg}$. Animals seem on the march in a mixed flock (fig. $10 \mathrm{~b}$ ) were very variable, some apparently being grey. Others seen at a show had wool finer than carpet type, the fleece being more like that of a hairy Shetland or the Greek Chalkidiki breed. The structure and colour of the fleece suggest a relationship with the European type of the present paper, but the possession of a fat tail implies a different broad grouping, and suggests either that this fleece structure and colour range had evolved before the fat tail developed, or that the same fleece characteristics evolved independently in different broad groups. 
The Kulunda breed was seen on the steppe of the same name in the Altai region of Siberia. Although located several thousand miles away it appeared superficially similar to the Karachaev, being a black, fat-tail Not all the sheep had a fat tail, however, and there were both horned and polled animals. As with the Karachaev the fleece appeared to be of hairy medium rather than a true hairy type. Most of the animals were black, but there were a few grey and brown animals, as well as white sheep, which may have been crossbred (fig. $10 \mathrm{c}$ ).

\section{Discussion}

Some of the breeds should perhaps have not been included in this survey, and there may well be other known, or more important, unknown, breeds that should have been included. But it is hoped that the present descriptions, however, inadequate, will stimulate more detailed studies of the breeds in question, as well as stimulate the search for little known breeds worthy of being put on record.

Several authors have used a diffusion model not only to study the spread of domesticates, but to estimate the rate of genetic change (e.g. LAUVERGNE, 1979). Such a model may work with plants, but has severe limitations with animals : waves of migration did not radiate outwards in regular fashion, but followed fairly narrow routes which differed in their rate of progress, and evolution was not restricted to the centre of origin.

If one accepts the evidence of PopLIN (1979) that the Mouflon sheep on Corsica are not truly wild but feral domesticates then here we have a survival of European Neolithic sheep that is little, if any, changed from the wild ancestor. Survival has however, depended more on the isolation of an island than on the distance from the centre of domestication.

The next most primitive breed, the Bronze Age Soay, is located on the very edge of the continent, but again survival was due to insular isolation. Most of the breeds of the present survey are thought to date from the Iron Age to the Middle Ages, and these are apparently scattered at random throughout Europe, although it is perhaps significant for the diffusion hypothesis that they are universal throughout northern Europe. The criteria on which these were chosen are the possession of a short tail, a primitive fleece structure, and in particular, a range of colour. It is not implied that these have undergone no selective change since the Iron Age (although the Soay appears not to have changed) since the colour range of some has been restricted, and they are clearly very variable.

Other factors casting doubt on the diffusion model are the location of the Merino, the breed with the most highly evolved fleece, in Spain a long distance from the centre of domestication in the Middle East, while the modern sheep at the centre of domestication appear primitive rather than highly evolved, although the hairy, carpet-type fleeces of these are now thought not to be primitive but relatively highly evolved (see fig. 4). It is however, difficult to define "primitive» and "highly evolved $"$ in this context, and in any case some breeds have both primitive and highly-evolved characters, the carcass in the Merino for example not being well developed. 
One can speculate that the best fit of a diffusion model to the observed or likely sheep distribution in Europe took place about 1000 B.C. Then the true fine (Merino) fleece was appearing in the Middle East, but had not yet begun to spread around the Mediterranean (RYDER, 1982). The varie-coloured type is likely to have advanced some distance into South East Europe (i.e. assuming that it had not evolved independently in at least one location in Europe itself), and further north and west the Soay is likely to have been the main type, while in outlying areas of northern Europe (and islands such as Corsica) the Neolithic «hair» sheep was probably still dominant. But even the most cursory knowledge of the numerous migrations across Europe since that time, must dissuade one from expecting the present distribution to give more than the vaguest hints about movements and evolutionary changes. At the outset of the present survey, for instance, I was expecting to find remnants of the true fine wool that must have existed in South East Europe in classical times, but in the event it was apparently the more primitive vari-coloured type that has survived.

Having cautioned against the over-optimistic use of a diffusion model, one must nevertheless accept that there is still considerable scope for the use as «markers » of such genes as those for colour, as suggested by LAUvERGNe (1979). Mutations observed by ADALSTEINSSON (1970) in Icelandic sheep from «mouflon-pattern 》 to white, from white to self-colour, and from self-colour to grey suggest one way in which the range of colour described in the present paper could have arisen (fig. 8). Another way of obtaining white animals would have been to select for greater and greater areas of white in piebald (spotted) animals (LAUvergne, 1975). This would, however, have resulted in recessive-white sheep, and breeds of this type apparently do not exist. Since coloured animals in modern breeds frequently have white markings Adalsteinsson (1977) considers that this indicates selection for white in combination with the spotting gene.

Since neither method of selection is likely to have affected the colour genes, these are almost certainly still present in modern breeds, but are masked by the inhibiting white and spotting genes. If therefore the colour genes could be revealed by crossing with homozygous recessive brown rams, breed relationships might be elucidated (Ryder \& Stephenson, 1968) (see also pp. 321-322 of Ryder, 1980).

Reçu pour publication en octobre 1981.

\section{Résumé}

Revue des races ovines européennes primitives

Cet article considère les moutons primitifs d'Europe (c'est-à-dire non améliorés) en utilisant des données (en particulier pour le type de toison) en provenance de races reliques au lieu des restes osseux et textiles plus communément employés.

Du mouton néolithique il existe seulement des restes osseux et son pelage semble avoir été assez peu différent de celui de l'ancêtre sauvage non domestiqué. Des restes textiles montrent que le mouton de l'Age de Bronze possédait une toison encore brune mais moins crineuse que celle du Soay qui subsiste à l'état marronné sur l'île de Saint Kilda, au nord-ouest de l'Ecosse. Les mesures faites sur les restes textiles, aussi bien que sur les toisons des moutons reliques, montrent que cette toison moins crineuse est en fait très variable, depuis un type relativement crineux jusqu’à une toison lainée. 
Les restes textiles montrent que le mouton blanc apparaît à l'Age de Fer. Beaucoup de laines cependant étaient encore coloréss ayant soit 100 p. 100 de fibres pigmentées (noires ou brunes), quelques fibres pigmentées (gris ou rouan) ou aucune fibre pigmentée. Les races reliques de ce type (souvent avec une courte queue de type primitif) ont une structure de toison semblable à celle du Soay mais avec un éventail de couleurs, blanc, noir et gris en plus du brun du Soay de l'Age de Bronze. Dans le présent article, c'est ce type qui est principalement étudié. C'était probablement le type prédominant en Europe jusqu'à ce que, après le Moyen Age, les races améliorées modernes aient commencé à apparaître.

Les races décrites, que l'on pense pouvoir faire remonter à l'âge de fer, sont divisées entre les groupes suivants : le groupe Nordique à queue courte qui comprend le Romanov de Russie, le Finnois, Landrace, l'ancien mouton de Gotland en Suède, le Spaelsau de Norvège, le Faroe, l'Islandais, l'Orkney-Shetland, le Quatre cornes britannique et le Cladagh d'Irlande. Les races Corse et Oliessant de France sont placées, avec le Guirra d'Espagne, dans le même groupe Sud-Ouest. Quant aux trois races de bruyère, le Drenthe des Pays-Bas. le Heidschnucke d'Allemagne, et le Wrzosowska de Pologne, on les a rangées dans un groupe des Plaines Nord de l'Europe.

Un groupe alpin comprend le mouton des Grisons de Suisse, le Steinschaf d'Autriche, le Della Roccia d'Italie, ainsi que d'autres races d'Italie, le Massa et le Carapelle. Le groupe balkanique comporte le Racka de Hongrie, le Dubrovnik de Yougoslavie, ainsi que le Karakachan et le Karnobat de Bulgarie et le Drama et le Chalcidique de Grèce. Il a aussi été possible d'introduire deux races d'U.R.S.S., le Karachev du Caucase et le Kulunda de Sibérie qui est cité pour être plus complet.

\section{References}

Adalsteinsson S., 1970. Colour inheritance in Icelandic sheep. J. agr. Res. Icel., 2, 3-135. Adalsteinsson S., 1977. Personal communication.

Adalstein S., Lauvergne J.-J., Boyazoglu J.G., Ryder M.L., 1978. A possible genetic interpretation of the color variants in the fleece of the Gotland and Goth sheep. Ann. Génét. Sél. anim., 10, 329-342.

Adalsteinsson S., Wardum H., 1978. Frequency of color genes in Faeroe Islands sheep. J. Hered., 69, 259-262.

Balevska R.K., Petrov A., 1972. Zackel sheep of Bulgaria and south eastern Europe. Bulg. Acad. Sci. Sofia.

DE Beer G., 1965. Genetics and prehistory. The Rede Lecture, Camb. Uni. Press.

Brooke C.H., Ryder M.L., 1977. Characteristics of some less-common breeds of sheep in southern Europe : a preliminary survey. Ann. Génét. Sél. anim., 9, 163-180.

Brooke C.H., Ryder M.L., 1979. Declining breeds of Mediterranean sheep. F.A.O. Animal Prod. and Health Paper 8, F.A.O., Rome.

Ekman S., 1964. The Gotland sheep. Z.f. Saugetierkunde, 29, 129-145.

EWART J.C., 1919. The intercrossing of sheep and the evolution of new varieties of wool. Scott. J. Agric., 2, 159-169.

LAUVergne J.-J., 1975. Génétique de la couleur de la toison des trois races ovines françaises, Solognote, Bizet et Berrichonne. Ann. Génét. Sél. anim., 7, 263-276.

LAUVERGNE J.J., 1976. A propos de la coloration du mouton d'Ouessant de type traditionnel. Département de Génétique animale, I.N.R.A., C.N.R.Z., Jouy-en-Josas, 2 p. ronéoté.

Lauvergne J.J., 1980. Compte rendu de mission en Bulgarie : La conservation des stocks génétiques domestiques en Bulgarie. Département de Génétique animale, I.N.R.A., C.N.R.Z., Jouy-en-Josas, 15 p. ronéoté. 
Lauvergne J.J., Adalsteinsson S., 1976. Gènes pour la couleur de la toison de la brebis Corse. Ann. Génét. Sél. anim., 8, 153-172.

LaUvergne J.J., Bottema S., 1979. Variants colorés chez le mouton Néerlandais des Landes de Bruyère (Heideschaap). Ann. Génét. Sél. anim., 11, 1-6.

Lauvergne J.J., Burrill Melinda Jane, Dolling C.H.S., Dennis Wendy, 1981. Fading with light and greying with age in the fleece of black australian Polwarth sheep. Ann. Génét. Sél. anim., 13, 93-110.

Mason I.L., 1967. The Sheep Breeds of the Mediterranean. F.A.O. and Commonwealth Agricultural Bureau Farnham Royal, U.K.

Nawara N., 1976. Restitution of valuable characters of the declining Polish sheep breed "Wrzosowka» with regard to fecundity and coat utility. Paper presented at the 27th Meeting of the European Assn. for Anim. Prod., Zurich.

Noddle B.A., Ryder M.L., 1974. Primitive sheep on the Aran Islands. J. Arch. Sci., 1, $109-112$.

Poplin F., 1979. Origin of the Corsican Mouflon in a new palaeontological perspective : by feralising. Ann. Génét. Sél. Anim., 11, 133-143.

Ryder M.L., 1962. The histological cxamination of skin in the study of the domestication of sheep. Z. Tierzucht. Zuchtsbiol., 77, 168-171.

Ryder M.L., 1964 a. The history of Sheep Breeds in Britain. Agric. Hist. Rev., 12, 1-12, 65-82.

Ryder M.L., 1964 b. Fleece Evolution in Domestic Sheep. Nature, 204, 555-559.

Ryder M.L., 1968 b. The evolution of Scottish Breeds of sheep. Scott. Stud., 12, 127-167.

RYDER M.L., 1968 b. Fleece structure in some native and unimproved breeds of sheep. Z. Teirzüicht. Züchtsbiol., 85, 143-170.

RYDER M.L., 1969 a. Changes in the fleece of sheep following domestication (with a note on the coat of cattle), pp. 495-521, in Ucko P.J. and Dimbleby G.W. (Eds.), The Domestication and Exploitation of Plants and Animals, Duckworth, London.

Ryder M.L., 1969 b. The sheep and wool of Ireland. J. Bradford Textile Soc., 1968-1969, 89-98.

RYDer M.L., 1970. The rural economy of prehistoric Denmark. Span, 13 (2), 98-101.

RYDER M.L., 1973. The use of the skin and coat in studies of changes following domestication, pp. 163-168 in Matolcsi J. (Ed.), Domestikationforschung und Geschichte der Haustiere, Akademiei Kiado, Budapest.

Ryder M.L., 1974 a. Wools from Antiquity. Text. Hist., 5, 100-110.

RYDER M.L., 1974 b. Fleece measurements of some miscellaneous native and unimproved breeds of sheep. J. Text. Inst., 65, 13-19.

RYder M.L., 1974 c. The saga of the Orkney sheep. The Ark, 1 (5), 12-17.

RYDER M.L., 1975. Development, structure and seasonal change in the fleeces of unimproved Scottish Blackface sheep from the Hebrides. J. agric. Sci., Camb., 83, 85-92.

RYDER M.L., 1976. Why should rare breeds of livestock be saved ?, pp. 244-249 in Olney P.J.S. (Ed.), International zoo yearbook, vol. 16.

RYDER M.L., 1980. Fleece colour in sheep and its inheritance. Anim. Breed. Abstr., 48, 305-324.

Ryder M.L., 1981. Wools from Vindolanda .J. Arch. Sci., 8, 99-103.

RYDER M.L., 1982. Sheep and Man, Duckworth, London (forthcoming).

Ryder M.L., Stephenson S.K., 1968. Wool Growth, Academic Press, London.

Ryder M.L., LAND R.B., Ditchburn R., 1974. Coat colour inheritance in Soay, Orkney and Shetland sheep. J. Zool., London, 173, 477-485.

Salvator L., 1897. Balearen in Wrt und Bild. Würzburg and Leipzig. 